\title{
Kursy repolonizacyjne na Śląsku Opolskim w latach 1945-1950
}

\section{Repolonization courses in Opolian Silesia in 1945-1950}

\section{Streszczenie:}

W 1945 r. do Polski przyłączono Śląsk Opolski, który objęto wówczas akcją repolonizacyjną, mającą na celu usunięcie wszelkich śladów niemieckiej przeszłości regionu i jego mieszkańców. Celem tego przedsięwzięcia było stworzenie niepodważalnego argumentu dowodzącego jego polskości. Jednym z elementów akcji były kursy repolonizacyjne, w których pod presją ogólnej sytuacji społeczno-politycznej wzięło udział ponad 93 tys. śląskiej młodzieży i osób dorosłych. Ślązaków uczono w ten sposób historii i geografii Polski oraz poprawnego posługiwania się językiem polskim w mowie i piśmie, aby w ten sposób stali się żywym dowodem potwierdzającym słuszność aspiracji Polski do tego terytorium, a także by ich trwale zintegrować z polskim społeczeństwem.

Słowa kluczowe: Śląsk Opolski, Górny Śląsk, kursy repolonizacyjne

\begin{abstract}
:
In 1945 Opolian Silesia was attached to Poland. At that time, Opolian Silesia was embraced by an action of repolonization which aim was to eliminate all German remains of the region and its inhabitants. The aim of this venture was to create an irrefutable argument which proves its Polishness. One of the elements of this action were repolonization courses. Under the pressure of
\end{abstract}


Janusz Pfaff - Kursy repolonizacyjne na Śląsku Opolskim...

socio-political situations 93 thousand of Silesian youth and adults took part in these courses. In this way, Silesians were taught the history and geography of Poland and also how to use the Polish language correctly in both writing and speaking. What is more, Silesians became a living proof which confirms the righteousness of Polish aspiration to this territory and also to permanently integrate them to Polish society.

Key words: Opolian Silesia, Upper Silesia, repolonization courses

\section{Wprowadzenie}

Pod koniec II wojny światowej do państwa polskiego przyłączono ogromne obszary odebrane Niemcom, wcześniej nazywane Ziemiami Postulowanymi, a od 1945 r. - Ziemiami Odzyskanymi, podporządkowanymi Ministerstwu o tej samej nazwie ${ }^{1}$. Niewielką stosunkowo część tego terytorium zajmował Górny Śląsk, składający się z dwóch części, mających różne doświadczenia historyczne: przedwojenne województwo śląskie (powstałe z terenów przyłączonych do Polski w 1922 r.) i niemiecka rejencja opolska - od 1945 r. powszechnie nazywana Śląskiem Opolskim lub Opolszczyzną. W 1945 r. obydwie części (wraz z Zagłębiem Dąbrowskim) połączono w jedno woj. śląskie (zwane początkowo śląsko-dąbrowskim). 6 VII 1950 r. utworzono z niego dwa odrębne: opolskie i katowickie. Przy czym część obszaru Opolszczyzny (rejon Bytomia, Gliwic i Zabrza) przyłączono do woj. katowickiego, a reszta (większość) stanowiła terytorialny rdzeń woj. opolskiego ${ }^{2}$. Ślązacy zamieszkujący woj. śląskie w czasie okupacji hitlerowskiej zostali wpisani na tzw. niemiecką listę narodowościową (Deutsche Volksliste, skr. DVL, potocz. Volkslista). W ich przypadku pojawiła się zatem konieczność masowej akcji rehabilitacyjnej, mającej na celu swego rodzaju ich polityczne „rozgrzeszenie”

\footnotetext{
1 Formalnie mocą dekretu Krajowej Rady Narodowej z 13 XI 1945 r., zob. Dziennik Ustaw Rzeczypospolitej Polskiej (Dz.U. RP), 1945, nr 51, poz. 295.

2 Ustawa z dnia 28 czerwca 1950 r. o zmianach podziału administracyjnego Państwa, Dz.U. RP, 1950, nr 28, poz. 255.
} 
i oczyszczenie z ciążącego na nich odium zdrady narodowej3. Inaczej wyglądała sytuacja Ślązaków z Opolszczyzny - w dokumentach urzędowych nazywanych tubylcami lub bardziej elokwentnie autochtonami. W przeciwieństwie do swych sąsiadów z przedwojennego województwa śląskiego, nigdy wcześniej nie posiadali obywatelstwa polskiego, tylko niemieckie. W latach hitlerowskiej dyktatury (19331944/5) podlegali presji wstępowania do wielu różnych prohitlerowskich organizacji, ponadto na skutek brutalnej germanizacji często nie znali języka polskiego w ogóle lub bardzo słabo. Dotyczyło to zwłaszcza dzieci i młodzieży. Z tych względów ich dalszy los nie przedstawiał się klarownie, z czego sami zdawali sobie sprawę. Już na samym początku, niemal w momencie zajęcia Śląska Opolskiego przez wojska radzieckie, problemy związane z jego rodzimi mieszkańcami stały się największym wyzwaniem, przed którym stanęły nowe władze polskie. Przede wszystkim nie było jednoznacznej opinii, czy mieszkańcy tego obszaru to Polacy czy też może Niemcy. Rozważano, co z tą ludnością począć - wysiedlić czy pozostawić? ${ }^{4} \mathrm{~W}$ takich okolicznościach narodził się pomysł przeprowadzenia masowej akcji weryfikacyjnej, mającej na celu komisyjne stwierdzenie narodowości każdego mieszkańca Opolszczyzny 5 .

Równolegle do akcji rehabilitacyjnej i weryfikacyjnej prowadzono zakrojoną na szeroką skalę tzw. akcję repolonizacyjną, której celem było pozbawienie Górnego Śląska i jego mieszkańców jakichkolwiek cech najszerzej rozumianej niemieckości. Jednym z głównych problemów był język, to znaczy - konieczność nauczenia Ślązaków poprawnej polskiej wymowy i pisowni oraz zmuszenia ich, by zaprzestali używania języka niemieckiego. Temu celowi miały służyć kursy repoloni-

${ }^{3}$ Szerzej o tej problematyce w: Z. Boda-Krężel, Sprawa Volkslisty na Górnym Ślq̨sku, Opole 1978, passim.

${ }^{4}$ Zagadnie to jest obszernie opisane w licznych publikacjach, m.in.: Z. Łempiński, Przesiedlenie ludności niemieckiej z województwa śląsko-dq̨browskiego w latach 19451950, Katowice 1979, passim; zob. też: B. Linek, Polityka antyniemiecka na Górnym Śląsku w latach 1945-1950, Opole 2000, s. 137 i nast.

${ }^{5}$ Szerzej o tym w: J. Misztal, Weryfikacja narodowościowa na Śląsku Opolskim 1945-1950, Opole 1984, passim. 
Janusz Pfaff - Kursy repolonizacyjne na Śląsku Opolskim...

zacyjne. Podczas posiedzenia Wojewódzkiej Rady Narodowej w Katowicach w dniach 29 i 30 I 1946 r. wojewoda gen. Aleksander Zawadzki powiedział m.in., że Ślązacy znaleźli się w trudnym położeniu i należy im pomóc odnaleźć się w nowej rzeczywistości. „Szczególnie problem wychowania w konsekwentnie polskim duchu młodzieży, to klucz do ostatecznego rozwiązania problemu repolonizacji"6.

Błędem byłoby sądzić, iż kursy repolonizacyjne to oryginalny pomysł polskich komunistów. Z badań przeprowadzonych przez Tadeusza Filipkowskiego ${ }^{7}$ (pracownika Ośrodka Badań Naukowych im. Wojciecha Kętrzyńskiego w Olsztynie) dowiadujemy się, że koncepcja wykorzystania szkolnictwa do potrzeb repolonizacyjnych na Ziemiach Odzyskanych zrodziła się i była poważnie traktowana przez polską konspirację działającą pod auspicjami Rządu RP w Londynie. Podczas okupacji hitlerowskiej Tajna Organizacja Nauczycielska powołała specjalny, kierowany przez prof. Jana Stanisława Bystronia, zespół pod kryptonimem „Piaski”, który zajmował się sprawami oświaty i kultury w Prusach Wschodnich. W jego skład wchodził m.in. późniejszy śląski kurator Oskar Kotula, mający już wtedy pewne doświadczenie wyniesione z pracy oświatowej, prowadzonej na Śląsku w okresie międzywojennym. Zespół „Piaski” miał wówczas za zadanie wypracowanie programu i metod repolonizacyjnych ludności warmińskiej i mazurskiej, cechującej się daleko posuniętym zgermanizowaniem. Równolegle z TON diagnostyczne prace nad całokształtem problematyki związanej z przejęciem przez Polskę Ziem Postulowanych/Odzyskanych przygotowywało Biuro Ziem Zachodnich (wcześniej jako Biuro Zachodnie, przy którym istniała - pod prezesurą biskupa katowickiego Stanisława Adamskiego - rada społeczna skupiająca przedstawicieli stronnictw politycznych i wybitnych reprezentantów świata na-

${ }^{6}$ A. Zawadzki, Notatki, przemówienia 1945-1948 na Ślq̨sku i w Zagłębiu Dąbrowskim, tekst autoryzowany, wybór W. Janiurek, W. Szewczyk, Katowice 1964, s. 135144.

7 T. Filipkowski, Repolonizacja ludności rodzimej Warmii i Mazur w latach 19451950, [w:] R. Rauziński, S. Senft (red.), Polska ludność rodzima na Ziemiach Zachodnich i Północnych po II wojnie światowej. Materiały z sympozjum naukowego w Instytucie Śląskim w Opolu w dniu 25 listopada 1988 r., Opole 1989, s. 37-39. 
uki). W pracach tych był zaangażowany zespół specjalistów z Uniwersytetu Poznańskiego, członków konspiracyjnej organizacji niepodległościowej „Ojczyzna”, którzy opracowali m.in. podstawowe założenia programowe polskiej polityki kulturalno-oświatowej w stosunku do ludności rodzimej tych ziem. Pracy oświatowej w procesie narodowego odnajdywania się Ślązaków, Pomorzan i Mazurów przypisywano szczególnie doniosłą rolę, jako najpotężniejszemu i najskuteczniejszemu narzędziu repolonizacji. Oświacie, jak przewidywano, miała przypaść przodująca rola odbudowy, odrodzenia, rozszerzania i utrwalania polskości na tych obszarach. Już wówczas oświatą zamierzano objąć także dorosłych. Nauczycieli, mających po wojnie pracować na obszarze Ziem Postulowanych/Odzyskanych, kształciły: Tajny Uniwersytet Ziem Zachodnich i Tajne Pedagogium w Warszawie. Inicjatorami utworzenia TP byli m.in. historycy pochodzący ze Śląska Cieszyńskiego, a potem przez wiele lat związani z ośrodkami naukowymi w Katowicach i Opolu: Kazimierz Popiołek i Alojzy Targ, oraz kierująca pracami TP Stefania Mazurek - zaangażowana w działalność oświatową w Bytomiu, a po wojnie wizytatorka oświaty na Śląsku. Tajna Wszechnica Polska, Komenda Pogotowia Harcerek, archiwiści i bibliotekarze prowadzili kursy wiedzy o tych ziemiach i tamtejszej sytuacji ludnościowej. Prace te, prowadzone przez osoby, organizacje i instytucje związane bezpośrednio lub współpracujące z Departamentem Oświaty i Kultury Delegatury Rządu RP na Kraj, trwały do połowy $1944 \mathrm{r}^{8}$

\footnotetext{
${ }^{8}$ T. Filipkowski, op. cit.; zob. G. Strauchold, Autochtoni polscy, niemieccy, czy... Od nacjonalizmu do komunizmu (1945-1949), Toruń 2001, s. 15-18; Oskar Kotula był ewangelikiem pochodzącym ze Śląska Cieszyńskiego, zob. Pismo bpa Stanisława Adamskiego do Wojewody Śląsko-Dąbrowskiego Aleksandra Zawadzkiego z 2 VIII 1945, Archiwum Archidiecezjalne Kurii Metropolitalnej w Katowicach (AAK), Kancelaria Biskupa Adamskiego (KBA), t. 96/I; O. Kotula przed II wojną światową pełnił m.in. funkcję zastępcy inspektora szkolnego miasta Łodzi, por. Podręczny poradnik dla kierowników i nauczycieli szkół powszechnych, red. W. Gacki, Łódź 1932, s. tytułowa (0. Kotula był współautorem); 0. Kotula to czołowy przywódca ruchu ludowego na Górnym Śląsku po II wojnie światowej, zob. F. Serafin, Ruch Ludowy w województwie ślasko-dąbrowskim w latach 1945-1949, Katowice 1970, s. 40, 144, 147-149, 154-155, 160, 166, 168; Z ruchem ludowym związany był też naczelnik Wydziału
} 
Janusz Pfaff - Kursy repolonizacyjne na Śląsku Opolskim...

Dlatego nie powinno też dziwić, że zwolennikiem polityki wysiedlenia Ślązaków zweryfikowanych jako Niemców i repolonizacji zweryfikowanych jako Polaków był także Stanisław Mikołajczyk (premier Rządu RP w Londynie, po wojnie w kraju wicepremier i czołowy przywódca antykomunistycznej opozycji jako prezes PSL), który zgadzał się w tej kwestii z oficjalnym stanowiskiem KC PPR. Również wyższe duchowieństwo Kościoła Katolickiego uznawało to za konieczne i zachęcało Ślązaków do nauki języka polskiego9.

Także materiały programowe do nauki na kursach repolonizacyjnych dostarczały dosyć rzetelnych informacji o „elemencie śląskim”. Pisano m.in.: „[...] Ciąży na nim dwuwarstwowość kultur: właściwa krajowi o charakterze narożnikowym (pogranicznym); kultura rodzima swoiście polska zamykająca się w obyczajach regionu śląskiego oraz nawarstwienie niemieckiej cywilizacji z którą związał się na skutek długiego pobytu w obcym społeczeństwie"10. Także w polskiej konspiracji podczas okupacji hitlerowskiej wyrażano obiektywne poglądy w obronie Ślązaków. Wskazywano, że w Ślązaku zakorzenione jest „rozdarcie nieustające między poczuciem kulturalnym własnym, tradycyjnym a narzuconym przemocą". Zalecano, by uszanować jego duszę, ukształtowaną "na modłę odrębną". Odnośnie działalności repolonizacyjnej władz, wskazywano by „Nie łamać, nie zacierać, nie równać gwałtem, tylko wyjaśniać, wyprowadzać z dziejów, wyplątywać z więzów, uzasadniać, właściwie komentować i po mału obejmować w posiadanie”. „Oni są narodem granicznym, rozdartym między dwa narody: polski i niemiecki, są bliscy krwią i duchem narodowi polskiemu, a upodobaniami i przyzwyczajeniami - niemieckiemu".

Oświaty i Kultury Dorosłych Kuratorium Okręgu Szkolnego Śląskiego (WOiKD KOSŚ) dr Maksymilian Hasiński, ibidem, s. 40.

9 Zob. P. Madajczyk, Przyłączenie Śląska Opolskiego do Polski 1945-1948, Warszawa 1996, s. 67, 219.

10 Materiały programowe do nauki na kursach repolonizacyjnych stopnia niższego i wyższego, Archiwum Państwowe w Katowicach (APK), Kuratorium Okręgu Szkolnego Śląskiego (KOSŚl.), t. 450. 
Nazywano Ślązaków „rekrutami polskości”, którzy na razie wyczuwają przede wszystkim swą odrębność ${ }^{11}$.

\section{Podstawy prawno-organizacyjne}

Podczas konferencji międzywydziałowej Urzędu Wojewódzkiego Śląskiego, która odbyła się w Katowicach 13 II 1945 r. pod przewodnictwem Stanisława Pieczykowskiego, delegata Ministra Oświaty, podjęto szereg decyzji dotyczących organizacji Kuratorium Okręgu Szkolnego Śląskiego (KOSŚ). Szczególną uwagę poświęcono Wydziałowi V, odpowiedzialnemu za oświatę osób dorosłych. Powierzono mu zadanie organizacji całokształtu oświaty pozaszkolnej tak, by „przez żywe słowo i pieśń polską oraz przez szerzenie znajomości Polski, jej dziejów i kultury zniwelować i wytępić szkodliwe wpływy niemieckie"12. Naczelnikiem Wydziału V został dr Maksymilian Hasiński, zaś Instruktorem Oświaty Dorosłych i jednocześnie kierownikiem Referatu kursów dla dorosłych został Franciszek Błach ${ }^{13}$. Pod koniec roku szkolnego 1945/46 F. Błach był pełniącym obowiązki wizytatora szkolnego, będąc jednocześnie zastępcą naczelnika Wydziału V KOSŚ14. Z początkiem roku szkolnego 1946/47 tytułował się już jako wizytator szkolny i zastępca naczelnika Wydziału V, oraz dodatkowo piastował stanowisko kierownika Referatu I Wydziału V, któremu w szczególności podlegały kursy repolonizacyjne. Zatem on był głównym bezpośrednim koordynatorem ich funkcjonowania na obszarze podległym KOSŚ15.

${ }^{11}$ Cyt. za: W. Wrzesiński, Postawy i nastroje Polaków na Górnym Śląsku w latach II wojny światowej, [w:] W. Wrzesiński (red.), Górny Śląsk i Górnoślazzacy w II wojnie światowej, Bytom 1997, s. 40-42.

12 Protokół z konferencji międzywydziałowej Śląskiego Urzędu Wojewódzkiego z 13 II 1945, APK, Urząd Wojewódzki Śląski (UWŚl.), Wydział Ogólny (Og.), t. 377.

13 Sprawozdanie (spraw.) WOiKD KOSŚ z 17 IV 1945 za okr. 1-15 IV 1945, APK, KOSŚl., t. 4.

14 Por. Plan pracy WOiKD KOSŚ na rok szkolny 1945/46, ibidem, t. 403.

15 Por. Organizacja WOiKDK KOSŚ wg stanu z 15 XI 1946, ibidem, t. 4. 
Janusz Pfaff - Kursy repolonizacyjne na Śląsku Opolskim...

17 II przejął urząd kuratora, a 19 II 1945 r. rozpoczął swą pracę kurator Jan Smoleń16. Jeszcze w tym samym miesiącu wyszedł z inicjatywą organizowania na Śląsku Opolskim kursów pod hasłem Poznaj Polskę, jej język, dzieje i kulturę ${ }^{17}$. Prawdopodobnie z tą też chwilą rozpoczęła się dyskusja władz wojewódzkich z centralnymi w sprawie organizowania na Opolszczyźnie kursów o charakterze repolonizacyjnym ${ }^{18}$. Nie czekając jednak na decyzje z Warszawy, jak również wykorzystując istniejący chaos, spowodowany trwającą jeszcze wojną oraz budowaniem niemal od podstaw zrębów nowego państwa polskiego, w dniu 7 III 1945 r. na konferencji Naczelników Wydziałów KOSŚ poświęconej organizacji szkolnictwa na terenie Górnego Śląska zostało przyjęte postanowienie „dostarczenia każdemu ośrodkowi człowieka, który będzie prowadził kursy języka polskiego”. W postanowieniu tym chodziło głównie o to, by ludność miejska i wiejska „w jak najkrótszym czasie nauczyła się mówić i czytać po polsku”. Taka argumentacja zawarta została w pisemnym projekcie organizacji szkolnictwa na Śląsku Opolskim, przekazanym przez kuratora na ręce wojewody A. Zawadzkiego ${ }^{19}$.

Tymczasem w opublikowanym 1 IV 1945 r. „Dzienniku Urzędowym Kuratorium Okręgu Szkolnego Śląskiego" ukazał się komunikat informujący w sposób ogólny, iż KOSŚ przystępuje do organizowania syste-

\footnotetext{
${ }^{16}$ Spraw. Kuratora Jana Smolenia, APK, UWŚl., Og., t. 377; Por. także O. Kotula, Szkolnictwo w województwie śląsko-dq̨browskim w latach 1945-1946, „Zaranie Śląskie" 1947, z. 1-2, s. 13; W. Długoborski, J. Pabisz, Walka z uciskiem narodowym i społecznym w latach 1922-1939, [w:] W. Długoborski (red.), Bytom. Zarys rozwoju miasta, Warszawa-Kraków 1979, s. 478. W publikacji tej jest jednakże podana błędna data rozpoczęcia pracy Smolenia jako kuratora, datowana na marzec; Jan Smoleń (1901-1945), przedwojenny nauczyciel matematyki, fizyki i chemii (Ruda Śląska, Bytom), działacz narodowy i oświatowy na Opolszczyźnie, przed II wojną światową aktywny członek Stronnictwa Ludowego, w okresie okupacji organizator tajnego nauczania na terenie woj. krakowskiego, zginął w wypadku samochodowym 28 VI 1945 r. w Karbiu (dziś dzielnica Bytomia) w czasie podróży służbowej, J. Kantyka, W. Zieliński (red.), Śląski Słownik Biograficzny, t. 2, Katowice 1979, s. 220-222.

17 Spraw. WOiKD KOSŚ za okr. 24 II 1945-24 I 1948, APK, KOSŚl., t. 412.

18 Por. J. Walczak, Jerzy Ziętek. Biografia Ślązaka (1901-1985), Katowice 2002, s. 546.

19 Projekt organizacji szkolnictwa na Śląsku Opolskim. Pismo kuratora J. Smolenia do wojewody A. Zawadzkiego z 13 III 1945, APK, UWŚl., Og., t. 378.
} 
matycznych kursów wieczorowych dla młodzieży pracującej i dorosłych na terenie przedwojennego woj. śląskiego pod hasłem Poznaj Polskę, jej dzieje i kulturę. Programem kursów objęto „podstawowe elementy nauki języka ojczystego oraz nauki o Polsce Współczesnej, jej dziejach i kulturze”. Obowiązek uczęszczania na kursy miał dotyczyć osób, które nie ukończyły polskiej szkoły dokształcającej lub średniej, „w szerszym zaś rozumieniu tych wszystkich, którzy wykazują braki w znajomości podstaw kultury ojczystej". Absolwenci kursów mieli otrzymywać stosowne świadectwa. Organizowanie kursów przekazano Instruktorom Oświaty Dorosłych, podlegającym powiatowym Inspektoratom Szkolnym. Komunikat zapowiadał, że bardziej szczegółowe informacje dotyczące sposobu organizowania i prowadzenia kursów ukażą się nieco później. Jednocześnie zwrócono się $\mathrm{z}$ apelem o pomoc i współpracę w organizowaniu kursów do wszystkich instytucji i organizacji społecznych ${ }^{20}$.

W tym samym numerze „Dziennika” kurator J. Smoleń ogłosił zasadnicze cele tego przedsięwzięcia: „Założenia i cele akcji są jasne i proste. Kursy mają dać możność każdemu obywatelowi polskiemu mieszkającemu na Śląsku zdobycia w stosunkowo najkrótszym czasie podstawowych wiadomości z dziedziny języka ojczystego i nauki o Polsce, jej głównych zagadnieniach, dziejach i kulturze. Pięć i pół roku ponownej niewoli, bezwzględnej germanizacji i straszliwego terroru nie zdołało zabić ducha polskiego na ziemi śląskiej, musiało jednak dokonać wielkich zniszczeń w świadomości narodowej i w poczuciu łączności kulturalnej szczególnie młodych pokoleń. Kursy wieczorowe to początek systematycznej planowej pracy nad leczeniem ran zadanych społeczeństwu śląskiemu przez okupanta [...]”. Kurator wezwał też do współpracy wszelkie organizacje i osoby. Ze względu na trwającą jeszcze wojnę i będący jej skutkiem ogólny chaos organizacyjny, kursy te z konieczności na początku miały być organizowane i prowadzone $\mathrm{w}$ miarę istniejących na danym terenie możliwości.

20 Dziennik Urzędowy Kuratorium Okręgu Szkolnego Śląskiego (Dz. Urz. KOSŚ), 1945, nr 1, poz. 30. 
Janusz Pfaff - Kursy repolonizacyjne na Śląsku Opolskim...

Przewidziano, że tymczasowo czas trwania kursu zamykać się będzie w 3-4 miesiącach. Tygodniowy plan zajęć miał obejmować minimum 6, a o ile będzie to możliwe - nawet 12 godzin. Każda lekcja miała się zaczynać i kończyć odśpiewaniem polskiej pieśni. Kursy miały być prowadzone na trzech „poziomach”: a) dla nie władających językiem polskim w stopniu umożliwiającym rozumienie wykładanego materiału w czasie lekcji, b) dla średnio władających językiem polskim, c) „dla względnie zawansowanych w znajomości języka polskiego”. Poszczególne grupy słuchaczy miały liczyć 25-30 osób. Nauczyciele mieli otrzymywać na bieżąco materiały do prowadzenia lekcji. Ośrodkami organizacyjnymi kursów miały być wszelkiego typu szkoły, instytucje kulturalne i oświatowe, zakłady pracy, urzędy, związki zawodowe itp. Każdy ośrodek organizacyjny miał mieć swego kierownika. Organizacja kursów i nadzór nad nimi w skali powiatu były domeną Instruktorów Oświaty Dorosłych pracujących w powiatowych Inspektoratach Szkolnych ${ }^{21}$.

Kilka dni później, 10 IV 1945 r. pismem skierowanym do Inspektoratów Szkolnych Śląska Opolskiego kurator zwrócił się tymi słowy: „Wobec tego, że z terenu Śląska Opolskiego nadchodzą do tut. Urzędu zapytania, czy i kiedy na terenie Śląska Opolskiego będą organizowane kursy języka polskiego dla dorosłych i młodzieży pozaszkolnej, wzywam Obywateli Inspektorów Szkolnych do jak najszybszego podjęcia w tym kierunku działalności organizacyjnych. Za podstawę w pracy tej przyjąć należy program i zasady organizacyjne kursów dla dorosłych prowadzonych pod hasłem «Poznaj Polskę, jej dzieje i kulturę» na terenie b. Województwa Śląskiego, a w miarę potrzeb program ten i zasady dostosowywać do wymogów tamtejszego terenu. [...] Należy dążyć do zorganizowania jak największej ilości kursów, a do współpracy wezwać wszystkie typy szkół istniejące na terenie.

21 Ibidem, poz. 31; Na początku kwietnia F. Błach, w imieniu Wydz. V KOSŚ odbył rozmowę z przedstawicielami Zarządu Wojewódzkiego Związku Walki Młodych w Katowicach w sprawie sposobu organizowania tego typu kursów dla członków ZWM, zob. Protokół z rozmowy przedstawiciela Wyd V KOSŚ F. Błacha z przedstawicielami ZW ZWM Halicką i Kozłowskim, APK, KOSŚl., t. 372. 
W braku sił nauczycielskich należy zwracać się po pomoc zarówno w organizowaniu kursów jak i w nauczaniu do pracowników z innych zawodów, nie wyłączając osób bez cenzusu naukowego, jednakże światłych, chętnych, władających poprawnie językiem polskim i dających rękojmię, że w pracy tej dadzą sobie radę"22.

Prace wokół organizowania kursów na Opolszczyźnie szybko posuwały się naprzód. 0 pierwszych sukcesach Wydział V KOSŚ informował już 15 IV 1945 r., donosząc m.in., że w powiatach Śląska Opolskiego kursy te organizowano przede wszystkim dla „Opolan” zatrudnionych w urzędach, oraz, że trwają przygotowania do uruchomienia dalszych 500 „kompletów” (zespołów/klas). Komisja redakcyjno-wydawnicza Wydziału V, którą kierowała Krystyna Walaszkowa, do tegoż czasu zdołała wydać drukiem Program języka polskiego i nauki o Polsce, oraz Materiały do nauki o Polsce, zeszyt 1, a w druku był już zeszyt 2. Pracowano także usilnie nad dalszymi materiałami dla nauczycieli. Nie wiadomo ile dokładnie do końca roku szkolnego 1944/45, który na Śląsku z konieczności praktycznie rozpoczął się dopiero pod koniec lutego 1945 r., zdołano zorganizować tych kursów na całym obszarze podległym KOSŚ. Wiadomo jedynie, że według stanu z 10 VII 1945 r. na obszarze powiatów samego tylko Śląska Opolskiego zdołano uruchomić 244 zespoły o łącznej liczbie słuchaczy 10 486, wśród których miażdżącą przewagę stanowiły kobiety - 7646 osób. Kursy te miały formę trzystopniową w zależności od poziomu wiedzy słuchaczy, i odbywały się w wymiarze 6-12 godzin tygodniowo, co z kolei zależało od istniejących na danym terenie możliwości. Program miał charakter próbny, tymczasowy, a czas jego realizacji obliczony był na ok. 4 miesiące (począwszy od marca 1945 r.). Jednakże z różnych przyczyn (brak nauczycieli, odpowiednich pomieszczeń i wyposażenia, wreszcie stałe przemieszczanie się strefy przyfrontowej na zachód, jak również brak chętnych kandydatów na słuchaczy) kursy w wielu miejscowościach rozpoczęły się później lub w ogóle nie zostały zorganizodem.

22 Pismo KOSŚ do Inspektoratów Szkolnych Śląska Opolskiego z 10 IV 1945, ibi- 
Janusz Pfaff - Kursy repolonizacyjne na Śląsku Opolskim...

wane, aczkolwiek w niejednym przypadku trwały aż do połowy sierpnia 1945 r. Oficjalnie funkcjonowały różne nazwy tych kursów, jak: kursy języka polskiego i nauki o Polsce, kursy nauki o Polsce, kursy repolonizacyjne. Ostatnia z wymienionych, choć początkowo rzadziej stosowana, w krótkim czasie stała się dominującą w różnych sprawozdaniach. Należy w tym miejscu powiedzieć, że kursy repolonizacyjne nie były jedynymi organizowanymi na obszarze Górnego Śląska. Były wplecione w całokształt akcji dokształcającej dorosłych. Kursy repolonizacyjne zasadniczo objęły ludność rodzimą zamieszkującą teren Śląska Opolskiego. Prowadzone później przez ten sam Referat kursy dla analfabetów były adresowane niemal wyłącznie do ludności napływowej, a kursy uzupełniające szkołę powszechną organizowano z myślą o dawnych mieszkańcach Zagłębia Dąbrowskiego i byłego woj. śląskiego 23 .

Trzeba też wyraźnie podkreślić, że w roku szkolnym 1944/45 kursy repolonizacyjne funkcjonowały jedynie w oparciu o wewnętrzne zarządzenia kuratora śląskiego, które nie opierały się na żadnych dyrektywach władz centralnych. Dopiero 6 VII 1945 r. Minister Oświaty wydał zarządzenie w sprawie organizacji kursów repolonizacyjnych na obszarze Ziem Odzyskanych (nr VII OD - 37/45 N). Zgodnie z nim nauczanie na kursach powinno trwać 6-10 godzin tygodniowo w ciągu 6 miesięcy. Organizowaniem kursów powinny się zająć szkoły i instytucje kulturalno-oświatowe z obowiązkiem złożenia sprawozdania Ministerstwu Oświaty do 15 IX 1945 r. W zarządzeniu zaznaczono też, że nauczyciele powinni uzbroić się w „pełne zrozumienie i życzliwość dla osób, które wykazują braki nie z własnej winy, lecz warunków politycznych i nacisku germanizacyjnego". Absolwenci mieli otrzymy-

23 Spraw. okresowe WOiKD KOSŚ za 1945, ibidem, t. 4 i 412; Spraw. ze stanu organizacji WOiKD KOSŚ z 17 IV 1945 za okres 1-15 IV 1945, ibidem, t. 4; Spraw. z działalności WOiKD KOSŚ za okres 24 II-VII 1945, ibidem; Spraw. WOiKD KOSŚ z organizacji poszczególnych form oświaty dorosłych wg stanu z 31 VIII 1945, ibidem; Spraw. WOiKD KOSŚ za okres II-20 IX 1945, ibidem; Spraw. WOiKD KOSŚ za okres 24 II-15 VII 1945, ibidem, t. 412. 
wać świadectwa ukończenia kursu ${ }^{24}$. Trzy tygodnie później, 27 VIII 1945 r. Minister Oświaty wystosował do Kuratorium pismo w sprawie programów dla kursów repolonizacyjnych (VII OD - 102/45 N)25. Zaś w dniu 29 VIII 1945 r. kurator Oskar Kotula (następca tragicznie zmarłego miesiąc wcześniej J. Smolenia) wydał zarządzenie adresowane do wszystkich Inspektoratów Szkolnych Okręgu Szkolnego Śląskiego, zatytułowane: „Kursy repolonizacyjne na terenach odzyskanych”, a zaczynające się słowami: „W powiatach Śląska Opolskiego dla ludności polskiego pochodzenia, która uzyskała obywatelstwo polskie, Inspektoraty Szkolne winny organizować masowo kursy pod hasłem: «Poznaj Polskę, jej język, dzieje i kulturę»”. Jednocześnie kurator udzielił pouczenia nauczycielom, iż „do tubylczej ludności polskiej, która uzyskała obywatelstwo polskie, należy się odnosić jak najżyczliwiej, otoczyć ją serdeczną opieką, aby ułatwić jej powrót duchowy do Macierzy"26. Zatem kursy repolonizacyjne ostatecznie przeznaczone i organizowane były dla zweryfikowanych Ślązaków zamieszkujących Śląsk Opolski, czyli tych, którym przyznano obywatelstwo polskie $^{27}$.

Wkrótce Wydz. V KOSŚ opracował własny plan pracy na rok szkolny 1945/46, który przewidywał m.in. masowe organizowanie kursów w powiatach Śląska Opolskiego, opracowanie i wydanie drukiem

\footnotetext{
24 Tekst zarządzenia zawiera praca: M. Siemieński, Zagadnienia szkolnictwa dla dorosłych. Organizacja - nauczanie, Kraków 1951, s. 102-103.

${ }^{25}$ Nie udało mi się bezpośrednio dotrzeć do tekstu tego zarządzenia. 0 jego istnieniu informuje Dziennik Urzędowy Ministerstwa Oświaty (Dz. Urz. Min. Ośw.), 1946, nr 7, poz. 218, oraz1950, nr 3, poz. 49; Z innego źródła wiadomo, że Ministerstwo Oświaty poleciło Kuratorium Okręgu Szkolnego Śląskiego poddać modyfikacji dotychczasowy program nauczania na kursach i specjalnie dostosować go do potrzeb ludności Ziem Odzyskanych, jak również opracować i wydać drukiem odpowiedni dla nich podręcznik (tzw. wypisy). Nie udało mi się ustalić kiedy takie polecenie wystosowano (być może zawarte zostało w tym samym zarządzeniu z 27 VIII 1945), zob. Spraw. WOiKD KOSŚ za okres 25 II 1945-1 I 1946, APK, KOSŚl., t. 404.

26 Pismo KOSŚ z 29 VIII 1945 do Inspektoratów Szkolnych Okręgu Szkolnego Śląskiego dotycz. zarządzenia w sprawie systematycznego kształcenia dorosłych w roku szkolnym 1945/46, ibidem, t. 24; Ten sam dokument w APK, Wojewódzka Rada Narodowa w Katowicach (WRN, Kat.), m-f 73522.

27 Por. Spraw. WOiKD KOSŚ za rok szkolny 1945/46, APK, KOSŚl., t. 412.
} 
Janusz Pfaff - Kursy repolonizacyjne na Śląsku Opolskim...

programów do nauczania języka polskiego i nauki o Polsce (na zlecenie Ministerstwa Oświaty), oraz tzw. wypisów (czytanek), które miały służyć 6 Kuratoriom Ziem Odzyskanych. Plan zapowiadał prowadzenie wizytacji kursów przez wizytatorów i okręgowych instruktorów oświaty. Planowano także zorganizowanie „w czasie jak najszybszym” referatu prac artystyczno-oświatowych, a także 1-2 amatorskich zespołów teatralnych, które z odpowiednio dobranym repertuarem miałyby odwiedzać środowiska wiejskie Opolszczyzny. Większość tych zadań zamierzano zrealizować już w pierwszym kwartale rozpoczynającego się roku szkolnego ${ }^{28}$.

Istotnie, jesienią 1945 r. KOSŚ nakładem Księgarni i Drukarni Katolickiej w Katowicach wydało drukiem w postaci broszury Ramowy program kursów dla dorosłych i młodzieży pozaszkolnej opatrzony innym nieco, niż do tej pory hasłem nagłówkowym: Poznaj Polskę - jej język, dzieje i kulturę, po czym rozesłano go pozostałym Kuratoriom działającym na Ziemiach Odzyskanych. Program ten, z polecenia Ministerstwa Oświaty, powstał poprzez modyfikację dotychczas stosowanego programu oraz dostosowanie go do potrzeb edukacyjnych ludności Opolszczyzny i pozostałych terenów Ziem Odzyskanych. Zawierał m.in. wytyczne, zgodnie z którymi kurs miał mieć strukturę dwustopniową. Na obydwu stopniach należało realizować ten sam program, z tym, że dla stopnia II przewidziano poszerzenie materiału gramatycznego oraz ewentualnie (nieobligatoryjnie) historii i geografii. Jednak zwrócono uwagę, że w zakresie języka polskiego należy położyć szczególny nacisk na praktyczne jego opanowanie, gramatykę zaś ograniczyć do niezbędnego minimum. Realizacja programu trwać miała przez 6-8 miesięcy w okresie 2 lat $\mathrm{w}$ wymiarze 6-10 godzin nauki tygodniowo. Program miał charakter ramowy i pozostawiał jego realizatorom swobodę w rozszerzaniu go czy zawężaniu „w zależności od potrzeb danego środowiska". Wszystkie lekcje miały się rozpoczynać i kończyć odśpiewaniem 1-2 zwrotek jednej z polskich

\footnotetext{
28 Plan pracy WOiKD KOSŚ na rok szkolny 1945/46, APK, KOSŚl., t. 403; Plan pracy WOiKD KOSŚ na I kwartał roku szkolnego 1945/46, ibidem.
} 
pieśni ludowych lub narodowych. Przy czym w pierwszym rzędzie należało skłonić słuchaczy do nauczenia się na pamięć słów hymnu Polski - Mazurka Dąbrowskiego, Roty Marii Konopnickiej, oraz pieśni Boże coś Polskę. Autorzy programu prognozowali, że w trakcie kursu repolonizacyjnego zostaną osiągnięte takie cele jak: uświadomienie słuchaczom historycznej łączności Ziem Odzyskanych z resztą Polski; pozyskanie wśród nich zwolenników nowej rzeczywistości społecznopolityczno-gospodarczej, w jakiej znalazła się Polska; kurs ma Ślązaków „zbliżyć” do polskiej kultury i literatury; zapewnić im „dostateczną znajomość i opanowanie mowy ojczystej" i polskiej pisowni, umiejętność „możliwie poprawnego” czytania ze zrozumieniem, oraz wzbogacenie ich „słownictwa polskiego"; „usunięcie z mowy potocznej słuchaczy naleciałości obcych, a zwłaszcza germanizmów"; oraz, iż program „Ma nauczyć słuchaczy nie tylko mówić, ale i myśleć po polsku, ma ich zjednoczyć z narodem". Podkreślono też, że kursantów należy zachęcać i ośmielać do „swobodnego używania języka ojczystego w takiej postaci (gwarze), w jakiej najłatwiej jest im opowiadać, zadawać pytania lub odpowiadać"29.

Program miał wyłącznie charakter ramowy, bardzo uogólniony. Dla konkretnych potrzeb nauczycieli Kuratorium opracowało obszerne i bardziej szczegółowe materiały do nauki na kursach repolonizacyjnych $^{30}$. Pod koniec stycznia 1946 r. KOSŚ zrealizowało inne polecenie Ministerstwa Oświaty, opracowując podręcznik zatytułowany: Nie rzucim ziemi! i wydając go drukiem w nakładzie 50 tys. egzemplarzy. Do końca tegoż roku szkolnego opublikowano także łącznie 4 zeszyty materiałów dydaktycznych dla nauczycieli kursów repolonizacyjnych ${ }^{31}$.

Na początku czerwca 1946 r. Ministerstwo Oświaty, wyrażając swą pozytywną opinię o kursach repolonizacyjnych, stwierdziło, że w roku

\footnotetext{
${ }^{29}$ Program ramowy kursów dla dorosłych i młodzieży pozaszkolnej, wyd. KOSŚ, Katowice 1945, ibidem, t. 450 i 404. Wyróżnienie w cytacie - JP.

30 Materiały programowe do nauki na kursach repolonizacyjnych stopnia niższego i wyższego, ibidem, t. 450.

31 Spraw. WOiKD KOSŚ za okres 25 II 1945-1 I 1946, ibidem, t. 404.
} 
Janusz Pfaff - Kursy repolonizacyjne na Śląsku Opolskim...

szkolnym 1946/47 nadal będą stanowiły ważną formę pracy na Ziemiach Odzyskanych. Ministerstwo podtrzymało w mocy swe zarządzenie z 6 VII 1945 r. Wyraziło także pełną aprobatę programu kursów i podręcznika Nie rzucim ziemi!, dodając przy tym, że na kursach repolonizacyjnych powinny być stosowane (po odpowiednim przystosowaniu) ogólne wskazania metodyczne i programowe zawarte w instrukcji z dnia 8 III 1946 r. (Dz. Urz. Min. Ośw., 1946, nr 2, poz. 49). Ponadto ustalono dolną granicę wieku słuchaczy - co najmniej 16 lat. Liczbę godzin na kursach ustalono na minimum 9 tygodniowo (3 dni po 3 lekcje). Organizatorów kursów zobowiązano do rzetelnego prowadzenia dzienników lekcyjnych. Postanowiono także, że absolwenci będą otrzymywać zaświadczenia stwierdzające fakt uczęszczania na kurs ${ }^{32}$.

Do wiosny 1946 r. kursy repolonizacyjne w zasadzie (pod względem formalnym) nie spełniały żadnego konkretnego celu, tzn. uczestnictwo w nich nikomu nie gwarantowało żadnych korzyści. Z punktu widzenia prawa nie było nawet żadnych wyraźnych podstaw uzasadniających ich organizowanie. Uczestnikiem kursu można było zostać jedynie z własnej nieprzymuszonej woli. Nie ukazał się żaden dokument o charakterze ustawowym, który by nakładał na kogokolwiek obowiązek uczęszczania na tego typu kurs. Ministerstwo Oświaty pismem z dnia 7 III 1947 r. wyjaśniło, że do czasu formalnego uregulowania sprawy nostryfikacji niemieckich świadectw szkolnych na Ziemiach Odzyskanych, jak również ustalenia podstaw formalnoprawnych istnienia kursów repolonizacyjnych, absolwentom tych kursów stopnia I i II należy wydawać zaświadczenia według jednolitego wzoru opracowanego przez Ministerstwo. Zaświadczenie zawierało zapis, że absolwent „ukończył kurs nauki o Polsce (repolonizacyjny) [...] na podstawie zarządzenia Ministra Oświaty z dnia 6 lipca 1945 r." Zaświadczenie takie mógł jednakże otrzymać jedynie ten absolwent, który wykazał się 75\% frekwencją oraz oceną dostateczną, czego jednak na zaświadczeniu nie odnotowywano. Dodatkowo Minister-

32 Dz. Urz. Min. Ośw., 1946, nr 7, poz. 218. 
stwo zwróciło uwagę, że absolwenci kursu stopnia II, niezależnie od otrzymania wspomnianego zaświadczenia, mogli w myśl rozporządzenia Ministerstwa Oświaty z dnia 1 IV 1946 roku (Dz. Urz. Min. Ośw., 1946, nr 3, poz. 76, szczególnie §12) przystępować do egzaminów z poszczególnych przedmiotów z zakresu materiału nauczania szkoły powszechnej, a w szczególności języka polskiego, historii i geografii Polski, oraz nauki o Polsce i świecie współczesnym, otrzymując na tej podstawie formalne świadectwo zaliczenia egzaminu $\mathrm{z}$ tych przedmiotów. Ministerstwo Oświaty zapowiedziało także, że jego zamierzeniem jest, by w przyszłości na podstawie przedłożenia świadectwa zdania egzaminu z tych przedmiotów oraz świadectwa ukończenia niemieckiej szkoły przeprowadzić nostryfikację świadectw poprzez wydanie odpowiedniego świadectwa równorzędnego ze świadectwem ukończenia szkoły polskiej33.

W instrukcji organizacji roku szkolnego 1947/48 z 13 VI 1947 r. Ministerstwo Oświaty stwierdziło, że organizowanie kursów repolonizacyjnych („kursów nauki o Polsce”) na obszarze Ziem Odzyskanych jest zagadnieniem tak ważnym, jak kursy dla analfabetów (organizowane $\mathrm{w}$ ramach akcji walki $\mathrm{z}$ analfabetyzmem). Ministerstwo, obok kursów I i II stopnia, zleciło również organizowanie kursów nauki o Polsce na poziomie szkoły średniej (niejako III stopnia) przygotowujących do egzaminu uzupełniającego przewidzianego rozporządzeniem Ministra Oświaty z dnia 12 IV 1947 r. Kursy te miały obejmować, oprócz języka polskiego, historii i geografii Polski, także co najmniej podstawowe elementy z zakresu przedmiotów nauczanych w szkole średniej, do której dany uczeń kandyduje. Przy czym dodano też: „za-

33 Ibidem, 1947, nr 3, poz. 80; zob. także Komunikat w sprawie zaświadczeń dla uczestników kursów dla dorosłych, ibidem, 1947, nr 2, poz. 53, wydany w nawiązaniu do Okólnika nr 1 z 7 I 1947 w sprawie wydawania świadectw ukończenia szkoły powszechnej dla dorosłych, ibidem, 1947, nr 1, poz. 9; por. również Rozporządzenie Ministra Oświaty z 12 IV 1947 w sprawie uznania świadectw osób dorosłych w zakresie szkoły powszechnej i średniej oraz zakładów kształcenia nauczycieli na Ziemiach Odzyskanych, ibidem, 1947, nr 3, poz. 62 i nr 5, poz. 96 (dwukrotnie publikowany). Czas obowiązywania tego przepisu przewidziano na okres 1 VI 1946-31 V 1953. 
Janusz Pfaff - Kursy repolonizacyjne na Śląsku Opolskim...

sady zaś nauczania winny być dostosowane do psychiki osób dorosłych oraz uwzględniać przeszłość narodową tej grupy Polaków, ofiar systemu germanizacyjnego" 34 .

W trakcie analizy zarządzeń Ministerstwa Oświaty z 1947 r., w których poruszana jest kwestia kursów repolonizacyjnych, nasuwa się spostrzeżenie, iż stopniowo dążono do ich restrukturyzacji. Wyraźnie zmierzano do tego, by ukończenie kursu było dla jego uczestników bardziej opłacalne w sensie praktycznym, by kursy te stały się pomostem do dalszego kontynuowania nauki. Poza tym coraz rzadziej używano nazwy „repolonizacyjne” zastępując ją coraz częściej określeniem „kursy nauki języka polskiego”35. 26 VI 1947 r. „Ministerstwo Ziem Odzyskanych poleciło wojewodom wydanie zarządzeń, które by położyły raz na zawsze kres upośledzaniu ludności stale osiadłej i określaniu jej w korespondencji służbowej jako «autochtonów», «zweryfikowanych» lub «obywateli Rzeszy Niemieckiej»". MZO pouczająco zwróciło uwagę, że Polskę zamieszkują jedynie obywatele polscy i cudzoziemcy. MZO poleciło karać winnych nadużyć w tym zakresie. KOSŚ pismem z 12 VII 1947 r. nakazało władzom oświatowym niższego szczebla ścisłe przestrzeganie tego polecenia ${ }^{36}$.

22 VI 1948 roku w Katowicach odbyła się konferencja poświęcona programowi kursów repolonizacyjnych, której przewodniczył F. Błach. Na jej zakończenie postanowiono m.in., utworzyć specjalną sześcioosobową komisję, która miała się zebrać w Raciborzu w dniach 6 i 7 VII 1948 r. celem opracowania nowego programu kursów repolonizacyjnych ${ }^{37}$. 20 VIII 1949 r. F. Błach w sprawozdaniu z działalności podległego mu Referatu I wysunął w imieniu całego Wydziału V po-

34 Ibidem, 1947, nr 8, poz. 180.

$35 \mathrm{Z}$ wypowiedzi nauczyciela kursu repolonizacyjnego w Stolarzowicach (powiat tarnogórski): „[...] Dlaczego użyto terminu repolonizacja - trudno mi było zrozumieć. [...] Z czasem zaniechaliśmy tego określenia, zmieniając je na bardziej odpowiednie: kursy języka polskiego", K. Demkowski, Pod znakiem rodła, [w:] K. Popiołek (red.), Wspomnienia nauczycieli śląskich, Katowice 1970, s. 17.

36 Dz. Urz. KOSŚ, 1947, nr 1, poz. 68.

37 Protokół z konferencji repolonizacyjnej w sprawie uwag i spostrzeżeń do programów państwowych kursów repolonizacyjnych, Katowice 22 VI 1948 (pod przewodnictwem F. Błacha), APK, KOSŚl., t. 450. 
stulat, by włączyć kursy repolonizacyjne w ramy organizacyjne kursów dla analfabetów (kursy początkowe nauki czytania i pisania). Argumentował to faktem, że uczestnicy obydwu typów kursów w zasadzie niczym szczególnym się nie różnią, a łączy ich jedno - nieumiejętność pisania i czytania po polsku ${ }^{38}$.

Tymczasem centralne władze oświatowe wyraźnie zmierzały do całkowitego przekształcenia kursów repolonizacyjnych, przede wszystkim poprzez podniesienie ich poziomu kształcenia i nadania im bardziej praktycznego charakteru. Myślano nawet o całkowitym zaniechaniu ich dalszego organizowania. W rzeczywistości w grę wchodziły względy polityczne - mówienie o repolonizacji świadczyło poniekąd, że istnieje jej potrzeba, co z kolei mogło podważać wszelkie głoszone przez stronę polską tezy o polskości tegoż obszaru, zatem mogło zostać wykorzystane przez zagranicznych zwolenników zwrotu Śląska Niemcom jako argument o charakterze niekorzystnym dla Polski. Ministerstwo Oświaty w opublikowanym 15 XI 1949 r. numerze swego Dziennika Urzędowego zamieściło komunikat, w którym w uzupełnieniu rozporządzenia Ministra Oświaty z dnia 12 IV 1947 r. w sprawie weryfikacji świadectw - informowało, że celem właściwego przygotowania kandydatów do egzaminów uzupełniających należy na kursach repolonizacyjnych realizować program nauczania odpowiedniej szkoły w zakresie języka polskiego, historii i geografii Polski oraz nauki o Polsce współczesnej. Jednocześnie Ministerstwo wycofało dotychczasowy ramowy program tych kursów jako „zdezaktualizowany w swoim ujęciu i zakresie materiału nauczania"39.

W niewiele ponad 3 miesiące później, 21 II 1950 r. Ministerstwo Oświaty opublikowało okólnik $\mathrm{w}$ sprawie zasad organizacyjnych i egzaminów ukończenia kursów nauki o Polsce. Na mocy tego okólnika straciły swą ważność: 1) zarządzenie z 6 VII 1945 r. (częściowo) w sprawie organizacji kursów repolonizacyjnych na ziemiach zachod-

\footnotetext{
38 Spraw. Referatu Systematycznego Kształcenia Dorosłych (RSKD) WOiKD KOSŚ za rok szkolny 1948/49, ibidem, t. 412.

${ }^{39}$ Dz. Urz. Min. Ośw., 1949, nr 15, poz. 261.
} 
Janusz Pfaff - Kursy repolonizacyjne na Śląsku Opolskim...

nich, 2) pismo z 27 VIII 1945 r. w sprawie programów dla kursów repolonizacyjnych, 3) pismo z 7 III 1947 r. w sprawie zaświadczeń ukończenia kursów repolonizacyjnych. Praktycznie zatem była to likwidacja kursów repolonizacyjnych. W ich miejsce wprowadzono dwojakiego rodzaju kursy nauki o Polsce, przygotowujące do egzaminu uzupełniającego w zakresie szkoły powszechnej względnie średniej. Kursy te miały trwać 1 semestr z możliwością przedłużenia do 2. Tygodniowo przewidziano 20 (szkoła powszechna) i 24 (szkoła średnia) godzin lekcyjnych, obejmujących nauczanie języka polskiego, historii i geografii Polski wraz z nauką o Polsce i świecie współczesnym. Program nauczania tych przedmiotów miał się równać programom nauczania szkoły powszechnej względnie średniej dla dorosłych w semestrach I-VI „z dostosowaniem do wieku i potrzeb zawodowych uczniów", wyraźnie nie poruszając w tym miejscu tematu przeszłości i świadomości narodowej kursantów. Kursy powinny kończyć się egzaminem uzupełniającym z wymienionych przedmiotów. Egzamin ten, wraz z przedłożonym świadectwem ukończenia odpowiedniej szkoły niemieckiej, stanowić miał podstawę do wydania świadectwa ukończenia polskiej szkoły powszechnej względnie średniej dla dorosłych 40 .

Niejako w odpowiedzi na to zarządzenie, KOSŚ (kierowane pod koniec swego istnienia przez kuratora Władysława Bachowskiego) w piśmie z 25 V 1950 r. do Departamentu Oświaty i Kultury Dorosłych przy Ministerstwie Oświaty informowało m.in.: „Na Śląsku Opolskim zachodziła konieczność nauczenia co najmniej około 200000 osób autochtonów języka ojczystego - czytania i pisania [...]. Nauka odbywała się na kursach nazywanych do niedawna niesłusznie repolonizacyjnymi. [...] Niejednemu wystarczyło, że opanował sztukę czytania i pisania po polsku i przestawał chodzić na kurs. [...] W czerwcu 1949 r. - w czasie rejestracji analfabetów - uchwycono ponad 45000 osób na Śląsku Opolskim, które nie potrafią zupełnie czytać i pisać po polsku, mimo, że umieją dobrze czytać i pisać po niemiecku. [...] W po-

40 Ibidem, 1950, nr 3, poz. 49. 
wiatach Śląska Opolskiego istnieje w dalszym ciągu konieczność repolonizacji i przeszkolenia co najmniej 50000 ludzi. Ze względów politycznych idąc za wytycznymi Komitetu Wojewódzkiego PZPR i ob. Wojewody Jaszczuka Kuratorium nie używa już określenia «repolonizacja», «kursy repolonizacyjne» itp. Niemniej problem repolonizacji istnieje" 41 .

Zatem z końcem lutego 1950 r. kursy repolonizacyjne przestały istnieć jedynie formalnie. W rzeczywistości funkcjonowały nadal, a jedynie pod inną nazwą - kursy języka polskiego, posiadając zupełnie nowy status prawno-organizacyjny. W gruncie rzeczy nowy program kursów niewiele odbiegał od poprzedniego. Nadal jego podstawę stanowiły te same przedmioty nauczania. $\mathrm{W}$ kursach tych wciąż uczestniczyło bardzo wielu słuchaczy. Dla porównania, w sprawozdaniu Wydziału Oświaty Prezydium Wojewódzkiej Rady Narodowej w Katowicach z dnia 4 VII 1951 r. dotyczącym oświaty na terenie samego woj. Katowickiego w dalszym ciągu posługiwano się określeniem „kursy repolonizacyjne”, których na tym obszarze w roku szkolnym 1950/51 zorganizowano 145 dla 3987 słuchaczy. Przy czym w latach poprzednich liczby te na terenie samego woj. katowickiego przedstawiały się następująco: 1945/46 - 160 kursów z 3512 uczniami; 1946/47 odpowiednio 248 i 7 108; 1947/48 - 295 i 8415; 1948/49 - 163 i 4 827; 1949/50 - 193 i 5 03842. Jednak liczba zarówno słuchaczy, jak i organizowanych kursów coraz wyraźniej malała. Jeśli można wierzyć pewnej notatce z lutego 1952 r., to od marca 1945 r. do 14 II 1952 r. na obszarze samego tylko woj. katowickiego (w granicach z 1950 r.) odbyło się 1240 kursów z łączną liczbą absolwentów w wysokości 32887 osób. W połowie lutego 1952 r. prowadzono tu jeszcze jedynie 44 kursy, na które uczęszczało 692 słuchaczy. Kursy te organizowane były na terenie 6 powiatów: Bytom, Gliwice-miasto, Gliwice-powiat,

${ }^{41}$ Pismo KOSŚ do Departamentu Oświaty i Kultury Dorosłych przy Ministerstwie Oświaty z 25 V 1950, APK, KOSŚl., t. 450. Wyróżnienie w cytacie - JP.

42 Spraw. Wydziału Oświaty (WO) Prezydium WRN w Katowicach z 4 VII 1951, dotyczące osiągnięć Oświaty Dorosłych w województwie katowickim APK, KOSŚl., t. 411. 
Janusz Pfaff - Kursy repolonizacyjne na Śląsku Opolskim...

Lubliniec, Tarnowskie Góry, Zabrze ${ }^{43}$. W zestawieniu z danymi zawartymi w podsumowującym sprawozdaniu KOSŚ za okres od 1945 do 1 I 1950 r., w którym jest mowa o 93065 uczestnikach kursów repolonizacyjnch organizowanych na obszarze całego woj. śląskiego (w granicach z 1945 r.) liczby te nabierają cech wiarygodności. Jednak nie wiadomo czy chodzi tu o osoby, które jedynie „przewinęły” się przez kurs, czy też o te, które uzyskały świadectwo jego ukończenia ${ }^{44}$.

Poza tym okólnik z 21 II 1950 r. nie sprawił natychmiastowego przerwania prowadzenia dalszych zajęć na kursach repolonizacyjnych, które programowo trwały 2 lata. Okólnik jedynie stanowił rezygnację Ministerstwa Oświaty z uruchomienia pierwszego semestru w roku szkolnym 1950/51. Te kursy, które rozpoczęły się przed datą opublikowania okólnika kontynuowano nadal wedle starego programu, tzn. jeśli kurs rozpoczął się jesienią 1949 r., to kończył się po 2 latach, czyli wiosną $1951 \mathrm{r}$. Zrezygnowano jedynie (i to tylko oficjalnie) z nazwy „repolonizacyjne”.

\section{Realizacja i jej efekty}

Na podstawie bardzo szczegółowych, aczkolwiek miejscami zawierających pewne braki, danych statystycznych dotyczących kursów repolonizacyjnych prowadzonych w poszczególnych miejscowościach woj. śląskiego w roku szkolnym 1945/46 (sporządzonych rzekomo według stanu z dnia 31 I 1946 r., co - jak wynika z ich analizy - nie było prawdą) można z dużą dokładnością wyliczyć, że niespełna $94 \%$

43 Luźna notatka z datą 14 II 1952: Pomoc ludności rodzimej, ibidem, t. 372; Por. także Pismo WO Prezydium WRN w Katowicach dotyczące osiągnięć z zakresu oświaty dorosłych w województwie katowickim, ibidem, t. 411.

${ }^{44}$ Spraw. KOSŚ z akcji repolonizacyjnej z 25 V 1950, ibidem, t. 450; „Akcja repolonizacyjna w latach 1945-1951 objęła około 50 tysięcy mieszkańców ziemi opolskiej", M. Gąszczyński, Oświata dla dorosłych, [w:] T. Musioł (red.), Oświata na Opolszczyźnie w latach 1945-1959, Katowice 1961, s. 152; Józef Półturzycki twierdzi, że na obszarze podległym kuratorium śląskiemu w latach 1945-1950 kursy repolonizacyjne „objęły około 80 tysięcy uczących się i zatrudniały ponad tysiąc nauczycieli [...]”, J. Półturzycki, Rozwój i problemy szkolnictwa dla dorosłych w Polsce Ludowej, WrocławWarszawa-Kraków-Gdańsk 1972, s. 264. 
słuchaczy deklarowało, iż ich językiem ojczystym jest polski, a 6\% niemiecki. Wiekowo wyraźnie najwięcej słuchaczy mieściło się w przedziale 15-19 lat. Było także wielu w wieku 14 i 20 lat, oraz duża grupa mieszcząca się w przedziale 25-31 lat i starsi. Na kursach pracowało przeważnie 1-3 nauczycieli, sporadycznie więcej, nawet do 12. Czas trwania kursów daleki był od jednolitości, mieszcząc się w bardzo rozległym przedziale 3-16 godzin tygodniowo. Również daty rozpoczęcia poszczególnych kursów były przeróżne, począwszy od czerwca 1945 do lutego 1946 r., ale najczęściej w miesiącach jesiennych 1945 r. Zazwyczaj w dniu nauki lekcje trwały 3 godziny zegarowe $\mathrm{w}$ różnych dniach tygodnia, $\mathrm{w}$ godzinach popołudniowowieczornych pomiędzy $14^{00}$ a $22^{00}$. Do 10 VII 1945 r. zdołano uruchomić 244 kursy, na które uczęszczały 10483 osoby. Później liczby te dynamicznie wzrastały. 31 I 1946 r. funkcjonowało już 730 kursów z łączną liczbą słuchaczy 20,5 tys., dochodząc w lutym do 25 tys. Później jednak dość gwałtownie kursantów zaczęło ubywać, z końcem roku szkolnym 1945/46 sięgając 17,8 tys. W roku 1946/47 liczba słuchaczy wahała się pomiędzy 20,4 a 20,6 tys. Podobny stan odnotowano w roku 1947/48 - 20,2-21,6 tys., a nawet dochodząc do 24 tys. Zdecydowany spadek liczby kursantów nastąpił w roku 1948/49, która wiosną 1949 r. wahała się pomiędzy 15,6 a 14,17 tys., a w roku 1949/50 zniżając się do 13,8 tys. (1 I 1950 - 14,6 tys.). Początkowo znakomitą większość słuchaczy stanowiły kobiety, przy czym w kolejnych latach istniała tendencja wyrównywania się tych proporcji, zachowując jednak ciągłą przewagę kobiet, co w poszczególnych latach w przybliżeniu przedstawiało się następująco: 1945/46 65-67\%; 1946/47 59,7\%; 1947/48 55,2\%; 1948/49 53,1\%. Ok. 75\% słuchaczy to ludność wiejska. Liczba miejscowości, w których prowadzono kursy repolonizacyjne w zasadzie nie przekroczyła 500, z tym, że na terenie niektórych z nich organizowano po kilka kursów w różnych placówkach (szkoły, zakłady pracy itp.). Najwięcej kursów zdołano zorganizować w roku 1945/46 - ponad 700. W następnych latach było ich znacznie mniej, 430-550, czego częstym powodem były trudności 
Janusz Pfaff - Kursy repolonizacyjne na Śląsku Opolskim...

finansowe. Również największą ilość zespołów uczniowskich (klas) zdołano utworzyć w roku szkolnym 1945/46 - 730 (dane ze stycznia 1946). W szczytowym okresie roku 1946/47 istniało 716 zespołów, w roku 1947/48 649-678, w roku 1948/49 nastąpiło nagłe zmniejszenie się ilości zespołów - 475, w roku następnym jednak, 1949/50, stan ten uległ poprawie - 540 zespołów słuchaczy. Luki w materiałach źródłowych pozwalają jedynie oszacować, że ok. 20\% ogółu słuchaczy uczęszczało na kurs II stopnia, spośród których jeszcze mniejszy odsetek uzyskiwało zaświadczenie jego ukończenia. W zestawieniu z kryteriami rekrutacji na poszczególne stopnie kursu dowodzi to słabej znajomości języka polskiego wśród Ślązaków z Opolszczyzny. Dla porównania, w samym tylko 1945 r. - spośród wszystkich prowadzonych wówczas kursów repolonizacyjnych kursy stopnia II na Opolszczyźnie stanowiły zaledwie niecałe $16 \%$, podczas gdy na terenie przedwojennego woj. śląskiego stanowiły one aż $64,5 \%$ kursów obydwu stopni 45 .

\footnotetext{
45 Wszystkie powyższe obliczenia i oszacowania zostały przeprowadzone w oparciu o szczegółową analizę następujących źródeł: Sprawozdania opisowe WOiKD KOSŚ za różne okresy poszczególnych lat szkolnych 1945/46-1947/48, APK, KOSŚl., t. 404, 405, 412, 440; Tabelaryczne i opisowe zestawienia liczbowe dotyczące placówek kształcenia dorosłych na obszarze Śląska Opolskiego w latach 1945-1950, ibidem, t. 372, 412, 440, 450; Spraw. opisowe RSKD WOiKD KOSŚ z 20 VIII 1949 za rok szkolny 1948/49, ibidem, t. 412; Spraw. KOSŚ z akcji repolonizacyjnej z 25 V 1950, ibidem, t. 450; Liczne "formularze sprawczo-statystyczne dla kursów dokształcających i szkół powszechnych dla dorosłych na rok szkolny 1945/46", zawierające dane dotyczące kursów repolonizacyjnych według stanu z 31 I 1946, a organizowanych na terenie powiatów: Bytom, Gliwice, Głubczyce, Katowice, Kluczbork, Koźle, Lubliniec, Niemodlin, Nysa, Olesno, Opole, Prudnik, Racibórz, Strzelce, Zabrze, ibidem, t. 417, 420, 421, 423, 424, 425, 426, 427, 428, 429, 430, 431, 433, 435, 439; Protokół z posiedzenia Wojewódzkiej Komisji Oświatowej z 28 IV 1948, APK, WRN Kat., m-f 73525; Dokument: Szkolnictwo i oświata przedszkolna, APK, UWŚl., Wydział SpołecznoPolityczny (SP), t. 69/1; Kurator 0. Kotula wiosną 1947 r. informował, że w latach 1945-1946 zorganizowano 385 kursów repolonizacyjnych z liczbą 28929 uczniów, O. Kotula, Szkolnictwo w województwie ..., s. 19; zaś naczelnik WOiKD KOSŚ M. Hasiński podał do publicznej wiadomości, że wiosną 1947 r. w istniejących 365 kursach repolonizacyjnych uczestniczyło 17066 słuchaczy podzielonych na 549 oddziałów, M. Hasiński, Praca kulturalno-oświatowa na Opolszczyźnie, „Zaranie Śląskie” 1947, z. 1-2, s. 20; Pochodzące z roczników statystycznych dane dotyczące kursów repolonizacyjnych nie przedstawiają naukowej wartości, są niepełne i wyraźnie zaniżone,
} 
Tyle mówią źródła. Dla porównania warto tu jeszcze przytoczyć dane liczbowe dotyczące wieku uczestników kursów repolonizacyjnych prowadzonych na terenie całego kraju w całym okresie ich funkcjonowania: do lat $17-37 \%, 18-21$ lat - 35\%, 22-25 lat - 16\%, powyżej 25 lat - 12\%, czyli 88\% to ludzie młodzi mający nie więcej niż 25 lat ${ }^{46}$. Wśród słuchaczy kursów repolonizacyjnych (zwłaszcza w początkowym okresie) przeważały kobiety. Zjawisko to było powszechne także na innych terenach Ziem Odzyskanych, np. na Warmii i Mazurach, gdzie w 1945 r. 77,5\% uczestników kursów repolonizacyjnych stanowiły kobiety ${ }^{47}$. Przyczyn było co najmniej kilka: ogólna przewaga liczebna kobiet w ówczesnej strukturze ludności (nie tylko Ślązaków) spowodowana stratami wojennymi wśród mężczyzn, masową wywózką górników na przymusowe roboty do ZSRR i rezygnacją powrotu do domu z wojennej tułaczki (głównie z obawy przed represjami na tle politycznym) ${ }^{48}$; na młodych chłopcach spoczywał $\mathrm{w}$ tym okresie obowiązek utrzymani całej rodziny, a w tym czasie istniało na Górnym Śląsku duże zapotrzebowanie na pracę $\mathrm{w}$ kopalniach, gdzie $\mathrm{w}$ tym okresie wykształcenie nie odgrywało większego znaczenia ${ }^{49}$; także

por. Rocznik Statystyczny 1948, GUS, Warszawa 1949, s. 204; Rocznik Statystyczny 1949, GUS, Warszawa 1950, s. 212; Rocznik Statystyczny 1950, GUS, Warszawa 1951, s. 145.

46 J. Półturzycki, op. cit., s. 266.

47 T. Filipkowski, op. cit., s. 48.

48 Z. Kowalski, Powrót Śląska Opolskiego do Polski. Organizacja władzy ludowej i regulacja problemów narodowościowych w latach 1945 - 1948, Opole 1983, s. 351352; R. Rauziński, Przeobrażenia społeczno-demograficzne ludności na Ziemiach Zachodnich w latach 1945-1985, [w:] Polska ludność..., s. 24; A. Sakson, Miejsce i rola ludności rodzimej w społecznościach lokalnych na przykładzie Warmii i Mazur w latach 1945-1956, [w:] ibidem, s. 71; S. Senft, Sytuacja polskiej ludności rodzimej na Ziemiach Zachodnich i Północnych w latach 1945-1956 (na przykładzie Ślq̨ska Opolskiego), [w:] ibidem, s. 112; G. Strauchold, op. cit., s. 68; Ok. 80-90\% mężczyzn-Ślązaków w wieku produkcyjnym w momencie zakończenia II wojny światowej przebywało poza miejscem swego zamieszkania, Z. Kowalski, op. cit., s. 261; 0 przewadze kobiet i starców w Bytomiu informował wicewojewoda Jerzy Ziętek w sprawozdaniu za lipiec 1946 skierowanym do Ministerstwa Ziem Odzyskanych, G. Strauchold, op. cit., s. 135; Por. też:: A. Dziurok, M. Niedurny (red.), Deportacje Górnoślq̨zaków do ZSRR w 1945 roku, Katowice 2004.

${ }^{49}$ K. Demkowski, op. cit., s. 21. 
Janusz Pfaff - Kursy repolonizacyjne na Śląsku Opolskim...

problemy związane z okresem dorastania - śląscy chłopcy bardziej niż dziewczyny odczuwali wstyd i zażenowanie nauką mówienia literacką polszczyzną ${ }^{50}$ (analogiczne zjawisko obserwowano w okresie międzywojennym wśród śląskich chłopców uczęszczających do szkoły51).

Zdecydowanie największą popularnością kursy repolonizacyjne cieszyły się w 1945 r., co prawdopodobnie było skutkiem presji ogólnej sytuacji przenikniętej atmosferą strachu przed wysiedleniem, pobytem w obozie, wywózką do ZSRR itp. Np. do nauczyciela pracującego w Zabrzu w dniu 18 IV 1945 r. zgłosiło się ok. 300 chętnych do udziału w kursie repolonizacyjnym. Tydzień później było ich już ponad 400, uczących się w 5 grupach po 80 osób. W ciągu kolejnych 5 dni liczba kursantów przekroczyła 500. Nauczyciel ten stwierdza ponadto, że wszędzie spotykał się z wielką życzliwością i ogromnym zapałem do nauki języka polskiego ${ }^{52}$. Inny nauczyciel, kierownik jednej ze szkół powszechnych na terenie powiatu strzeleckiego, mając na uwadze kursy repolonizacyjne wspomina, że „Nie było dnia, w którym nie byłoby w szkole zajęć wieczorowych"53. Mimo to urzędnicy wysokiego szczebla i przedstawiciele władz ciągle uważali, że liczba kursantów wciąż jest zbyt niska. Ze strony władz oświatowych wojewódzkich, jak też niższego szczebla, już niemal od początku akcji organizowania kursów repolonizacyjnych bezskutecznie wysuwano do władz centralnych postulat nałożenia mocą ustawy lub dekretu na zweryfikowanych Ślązaków obowiązku uczęszczania na nie ${ }^{54}$. Naczel-

50 F. Sławiński, Pierwsze kroki na odzyskanej ziemi, [w:] Wróciła Polska. Pamiętniki z pierwszych lat powojennych na Ziemiach Odzyskanych, wybór Z. J. Bolek, Warszawa 1974, s. 88.

51 A. Glimos-Nadgórska, Polskie szkolnictwo powszechne województwa śląskiego (1922-1939), Katowice 2000, s. 107-108.

52 A. Grajpel, Kartki z pamiętnika śląskiego nauczyciela, [w:] K. Popiołek (red.), Wspomnienia nauczycieli..., op. cit., s. 41-44, 52.

53 J. Śleziona, Pamiętnik polskiego rechtora, [w:] R. Hajduk (red.), Pamiętniki Opolan, Kraków 1954, s. 460.

54 Dokument: Praca kulturalno-oświatowa na Opolszczyźnie, APK, KOSŚl., t. 450; Pismo Naczelnika Wydz. IV KOSŚ z 9 VII 1945 do Inspektoratów Wydziału IV, Liceum Pedagogicznego w Tarnowskich Górach i Seminarium dla Wychowawców Przedszkoli 
nik Wydziału V apelował: „Egzekwowanie obowiązku ukończenia kursu repolonizacyjnego w stosunku do poszukujących pracy, wstępujących do organizacji zawodowych, społecznych, politycznych itp. winno wejść w praktykę danych organizacji i stanowiłoby formę nacisku były przychylne takim pomysłom. Kursy repolonizacyjne przez cały czas ich funkcjonowania miały jedynie charakter oferty skierowanej do zweryfikowanych Ślązaków, którą mogli przyjąć lub nie. Zgłoszenie się do udziału w kursie miał charakter dobrowolnej decyzji. Z politycznego punktu widzenia było to rozwiązanie słuszne, bo chroniło Polskę przed międzynarodowym zarzutem prowadzenia masowej polonizacji siłami represji.

Skoro na terenie całej Opolszczyzny łącznie zweryfikowano ok. 850 tys. osób ${ }^{55}$, to liczbę 93,065 tys. spośród nich (ok. 11\%), którzy w omawianym okresie uczestniczyli w kursach repolonizacyjnych, mimo wszystko należy ocenić jako bardzo wysoką ${ }^{56}$. Po odliczeniu dzieci i emerytów (łącznie około 32-35 tys.) odsetek ten wzrasta do ok. 18\% osób w wieku produkcyjnym ${ }^{57}$. Powody zapisywania się na kursy były różne. Najważniejsze to: obawa przed wysiedleniem (w tym rzeczywistych Niemców, którym udało się uzyskać pozytywną ocenę komisji weryfikacyjnych) i/lub jako argument polskości w procesie weryfika-

w Mysłowicach, dotyczące kursów dla niekwalifikowanych wychowawczyń przedszkoli, ibidem, t. 24; Sprawozdania WOiKD KOSŚ za rok szkolny 1945/46, ibidem, t. 404, 412; Spraw. Inspektoratu Szkolnego Bytom-powiat za rok szkolny 1948/49 z 22 VI 1949, ibidem, t. 413.

55 Por.: Z. Kosiński, Przeobrażenia demograficzne na Ziemiach Zachodnich, [w:] W. Markiewicz, P. Rybicki (red.), Przemiany społeczne na Ziemiach Zachodnich, Poznań 1967, s. 83; L. Olejnik, Ziemie Odzyskane w polityce narodowościowej państwa polskiego w latach 1945-1949, „Przegląd Zachodni” 1999, nr 3, s. 154.

56 Podobnie uważa Piotr Madajczyk, oceniając tę część Ślązaków, która została objęta kursami repolonizacyjnymi, jako „nie tak małą”, P. Madajczyk, Przyłączenie..., s. 197.

57 Szacunkowe obliczenia własne na podstawie analizy porównawczej ze stanem ludności Polski z połowy 2016 r., Ludność. Stan i struktura w przekroju terytorialnym. Stan w dniu 30 VI 2016 r., GUS, Warszawa 2016, s. 11. W szacunkach uwzględniono poprawkę wynikającą ze specyfiki stanu ludności Opolszczyzny pierwszych latach powojennych (wywózki mężczyzn do ZSRR, straty wojenne, dobrowolna pozostawanie na emigracji zdemobilizowanych żołnierzy itp.). 
Janusz Pfaff - Kursy repolonizacyjne na Śląsku Opolskim...

cji narodowościowej58; faktyczna chęć nauczenia się poprawnej polskiej wymowy i pisowni59; nadzieja zabezpieczenia się przed ewentualnym zamknięciem w obozie pracy lub innym (gdzie często działy się sceny dantejskie) ${ }^{60}$; uległość presji sytuacji oraz strach przed szykanami i mobbingiem ze strony pracodawców, polskiego antyniemiecko nastawionego sąsiedztwa, zbrojnych oddziałów antykomunistycznego ruchu oporu61.

Kursy repolonizacyjne dzieliły się na państwowe i prywatne przyzakładowe. Państwowe notorycznie cierpiały na braki finansowe, przyzakładowe były finansowane przez dane zakłady pracy. Niejednokrotnie trudności budżetowe były powodem zahamowania rozbudowy sieci kursów. Z braku funduszy wiele kursów nie było stać na kupno podręczników. Z tych samych powodów w roku szkolnym 1948/49 kursy repolonizacyjne z opóźnieniem rozpoczęły swą pracę, bo dopiero w listopadzie. W Kuratorium brakowało pieniędzy na godziwe wynagrodzenie nauczycieli pracujących na kursach. Z powodu niskich płac wielu z nich odchodziło. 0 pomoc w pozyskiwaniu dodatkowych funduszy KOSŚ zwracało się do wojewody, WRN w Katowi-

58 A. Grajpel, op. cit., s. 41; K. Demkowski, op. cit., s. 18; P. Madajczyk, Przyłączenie..., s. 171; także G. Strauchold, op. cit., s. 58, 68.

${ }^{59}$ S. Nowakowski, Adaptacja ludności na Śląsku Opolskim, Poznań 1957, s. 155; C. Osękowski, Społeczeństwo Polski Zachodniej i Północnej w latach 1945-1956. Procesy integracji i dezintegracji, Zielona Góra 1994, s. 131.

60 Por. P. Madajczyk, Przyłączenie..., s. 237-293; Szerzej o powojennych obozach na Górnym Śląsku zob.: G. Gruschka, Zgoda - miejsce grozy. Obóz koncentracyjny w Świętochłowicach, Gliwice 1998; A. Topol (red.), Obozy pracy przymusowej na Górnym Śląsku, Katowice 1994; P. Madajczyk, Obozy pracy na ziemiach zachodnich i północnych przed i po 1948 roku, [w:] C. Osękowski (red.), Ziemie Zachodnie i Północne Polski w okresie stalinowskim, Zielona Góra 1999, s. 89; A. Dziurok, Ślaskie rozrachunki. Władze komunistyczne a byli członkowie organizacji nazistowskich na Górnym Śląsku w latach 1945-1956, Warszawa 2000, s. 115-143; A. Dziurok (oprac.), Obóz pracy $w$ Świętochłowicach $w 1945$ roku. Dokumenty, zeznania, relacje, listy, Warszawa 2002.

61 Zob. Zarządzenie Pełnomocnika Rządu Tymczasowego na Województwo Śląskie z 29 I 1945 r. w sprawie likwidacji śladów okupacji niemieckiej, Gazeta Urzędowa Województwa Śląskiego, 1945, nr 1, poz. 6; P. Madajczyk, Przyłączenie..., s. 214217; Spraw. sytuacyjne Zarządu Miejskiego w Gliwicach z 7 I 1948, APK, UWŚl., SP, t. 69. W dokumencie tym jest m.in. stwierdzenie, iż „Akcja zwalczania mowy niemieckiej spowodowała wzmożoną frekwencję na kursa repolonizacyjne”. 
cach, jak również do Wojewódzkiej Rady Kultury ${ }^{62}$. Za dofinansowaniem kursów opowiadało się także (w styczniu 1949 r.) Ministerstwo Ziem Odzyskanych ${ }^{63}$.

Kursy repolonizacyjne były jednym z wielu narzędzi repolonizacyjnych, silnie związanym z weryfikacją. Poza tym repolonizacyjny charakter miały także inne placówki oświaty dorosłych, jak Uniwersytety Ludowe, świetlice, zespoły dobrego czytania. Mimo trudności finansowych i innych KOSŚ zdołało uruchomić z początkiem roku szkolnego 1947/48 w Państwowym Gimnazjum i Liceum dla Dorosłych w Opolu internatowy ośrodek repolonizacyjny. Była to w gruncie rzeczy szkoła średnia z internatem przeznaczona dla zweryfikowanych mieszkańców Śląska Opolskiego. Ze względu na dużą popularność, jaką ośrodek ten od razu sobie pozyskał, planowano uruchomienie kolejnej tego typu placówki w Prudniku64. Prócz tego uruchomiono w tym czasie kolejne internaty dla uczniów klas repolonizacyjnych przy Państwowym Gimnazjum i Liceum dla Dorosłych w Bytomiu, jak również w Prudniku. Uczniów tych przygotowywano do egzaminów uzupełniających. Wielu z nich otrzymywało stypendia w wysokości 15 tys. zł (Bytom) i 10 tys. zł (Prudnik) miesięcznie65.

${ }^{62}$ Spraw. WOiKD KOSŚ za poszczególne lata szkolne 1945/46, 1946/47, 1947/48, APK, KOSŚl., t. 404, 405; Spraw. WOiKD KOSŚ z wykonania budżetu za okres 1 VII 1945-31 III 1946, ibidem; Spraw. WOiKD KOSŚ, załącznik do pisma Wydziału Ogólnego z 23 IX 1948, ibidem; Plan pracy WOiKD KOSŚ na rok szkolny 1947/48, ibidem; Spraw. podinspektora WOiKD w Inspektoracie Szkolnym Gliwice-miasto za rok szkolny 1948/49, ibidem, t. 413; Spraw. opisowe RSKD WOiKD KOSŚ za rok szkolny 1948/49, ibidem, t. 412; Spraw. opisowe Inspektoratu Szkolnego w Zabrzumiasto z prac kulturalno-oświatowych wśród dorosłych w Zabrzu za rok szkolny 1948/49, ibidem, t. 414.

63 G. Strauchold, op. cit., s. 238.

${ }^{64}$ Dokument: Plan pracy w zakresie oświaty dorosłych na Opolszczyźnie w II półroczu 1946/47, APK, KOSŚl., t. 372; Plan pracy WOiKD KOSŚ na rok szkolny 1947/48, ibidem, t. 405; Spraw. WOiKD KOSŚ za rok szkolny 1947/48, ibidem; Program kursu przygotowawczego języka polskiego przy Państwowym Gimnazjum i Liceum dla Dorosłych w Opolu, ibidem, t. 372 i 450; S. Mazurek, Na tropach repolonizacji, „Odra”, nr 1 z 9 I 1949; Państwowe Gimnazjum i Liceum dla Dorosłych w Opolu w 1950 r. zarządzeniem Ministerstwa Oświaty przekształcono w Liceum dla Pracujących, G. Strauchold, op. cit., s. 183.

${ }^{65}$ Spraw. WOiKD KOSŚ za rok szkolny 1947/48, APK, KOSŚl., t. 405. 
Janusz Pfaff - Kursy repolonizacyjne na Śląsku Opolskim...

Mimo stosunkowo dużego zainteresowania Ślązaków kursami repolonizacyjnymi problemem była ich niska frekwencja uczęszczania na zajęcia. Jednym częstych powodów była praca zawodowa kursantów. Na zajęcia przychodzili bezpośrednio po pracy, zmęczeni i brudni. $\mathrm{Z}$ tego powodu opuszczali wiele lekcji, a nie potrafiąc nadrobić zaległości zniechęcali się i całkowicie rezygnowali z kursu66. Przykładowo, w Rybniku zauważono, że powodem braku zainteresowania kursami była bieda i bezrobocie - część mieszkańców tego miasta szukała pracy w pobliskiej Czechosłowacji. Inni zatroskani o zabezpieczenie bytu swych rodzin nie znajdywali już czasu na uczestnictwo w kursie ${ }^{67}$. Zniechęcający wpływ wywierała także „podziemna agitacja niemiecka". Potwierdziło to także KOSŚ cytowanym już pismem z maja 1950 r.68. Duża część ludności, licząc się z możliwością powrotu Śląska do Niemiec, z obawy przed ewentualnymi przyszłymi represjami ze strony władz niemieckich ustosunkowywała się wobec kursów repolonizacyjnych $\mathrm{z}$ rezerwą ${ }^{69}$. Także jedna $\mathrm{z}$ nauczycielek kursu repolonizacyjnego w Gliwicach w sprawozdaniu bez daty zwróciła uwage, że „Praca w kierunku całkowitej repolonizacji naszych terenów uzależniona jest od wpływów politycznych - dopóki nie będą ustalone granice zachodnie - dopóty pewna część ludzi będzie uczyła się języka polskiego ze względów praktycznych, ale nie będzie czuła się Polakami"70. Wizytator Stanisław Bożek w czasie wizytacji kursów repoloni-

${ }^{66}$ Spraw. z pracy kursu repolonizacyjnego przy szkole $\mathrm{nr} 16 \mathrm{w}$ Gliwicach i z kursu przy Głównych Warsztatach Wagonowych PKP w Gliwicach, APK, KOSŚl., t. 450; Spraw. opisowe Inspektoratu Szkolnego w Zabrzu-miasto z prac kulturalno-oświatowych wśród dorosłych w Zabrzu w rok szkolny 1948/49, ibidem, t. 414; Spraw. Inspektoratu Szkolnego Bytom-powiat za rok szkolny 1948/49 z 22 VI 1949, ibidem, t. 413.

67 Dokument: Spraw. z wyjazdu służbowego do Rybnika w dniu 12 III 1946, APK, KOSŚl, t. 410.

68 Pismo KOSŚ do Departamentu Oświaty i Kultury Dorosłych przy Ministerstwie Oświaty z 25 V 1950, APK, KOSŚl., t. 450.

${ }^{69}$ Sprawozdania WOiKD KOSŚ za rok szkolny 1945/46, APK, KOSŚl., t. 404 i 412; Spraw. podinspektora WOiKD w Inspektoracie Szkolnym Gliwice-miasto za rok szkolny 1948/49, ibidem, t. 413; por. P. Madajczyk, Przyłączenie..., s. 207.

70 Spraw. z pracy kursu repolonizacyjnego przy szkole $\mathrm{nr} 16 \mathrm{w}$ Gliwicach i z kursu przy Głównych Warsztatach Wagonowych PKP w Gliwicach, APK, KOSŚl., t. 450. 
zacyjnych w Strzelcach w grudniu 1947 r. stwierdził, że na stan niskiej frekwencji złożyły się takie przyczyny, jak brak samodyscypliny zarówno uczniów, jak i nauczycieli, słaby autorytet tych ostatnich, zła ogólna organizacja kursów, złe metody prowadzenia lekcji, oraz - jak to określono w sprawozdaniu - trudne miejscowe środowisko społeczne ${ }^{71}$. Z kolei wizytator F. Błach w związku z takim stanem rzeczy wnioskował, że celem zachęcenia ludności do uczęszczania na kursy należy przede wszystkim ich absolwentów otoczyć opieką w zakresie pomocy w uzyskaniu pracy oraz umożliwienia im dalszego kształcenia się w szkołach zawodowych ${ }^{72}$. Mimo, że na kursach przyzakładowych słuchaczami byli zazwyczaj ludzie wytypowani i częstokroć zmuszani przez władze zakładowe do uczęszczania na zajęcia, to właśnie tam frekwencja była najniższa. Niejednokrotnie przeszkodą w regularnym uczęszczaniu była praca na druga zmianę ${ }^{73}$. W ośrodkach wiejskich wyraźny spadek frekwencji miał miejsce wiosną każdego roku, kiedy to rozpoczynały się prace na roli, absorbujące ich całkowicie. Największy spadek frekwencji na kursach odnotowano na przełomie lat 1948 i 1949 co było skutkiem wydarzeń politycznych na arenie międzynarodowej w postaci silnego ochłodzenia w stosunkach Wschód - Zachód, a czego punktem kulminacyjnym był tzw. kryzys berliński, stanowiący bardzo realne zagrożenie wybuchu III wojny światowej. Potwierdził to w październiku 1949 r. wojewoda Bolesław Jaszczuk w sprawozdaniu kwartalnym Urzędu Wojewódzkiego, nazywając spadek frekwencji na kursach repolonizacyjnych jesienią 1949 r. „jaskrawym dowodem" panującego wśród Ślązaków nastroju niepewności wynikającego z lęku przed nowym światowym konfliktem zbrojnym,

\footnotetext{
${ }^{71}$ Spraw. wizytatora S. Bożka z wyjazdu służbowego do Strzelec i powiatu strzeleckiego odbytego w dniach 17-19 XII 1947, APK, KOSŚl.

72 Spraw. wizytatora F. Błacha z podróży służbowej do Raciborza i powiatu raciborskiego odbytej w dniach 26-29 I 1948, APK, KOSŚl, t. 410.

73 Spraw. podinspektora WOiKD w Inspektoracie Szkolnym Gliwice-miasto za rok szkolny 1948/49, ibidem, t. 413; Spraw. z pracy kursu repolonizacyjnego przy szkole nr 16 w Gliwicach i z kursu przy Głównych Warsztatach Wagonowych PKP w Gliwicach, ibidem, t. 450 .
} 
Janusz Pfaff - Kursy repolonizacyjne na Śląsku Opolskim...

mogącym skutkować powrotem Górnego Śląska do Niemiec ${ }^{74}$. Na nagły spadek zainteresowania kursami repolonizacyjnymi w tym czasie z całą pewnością wpływ miał także fakt zakończenia z początkiem czerwca 1948 r. akcji weryfikacji narodowościowej, z którą kursy te były silnie związane ${ }^{75}$. Do tego dochodziły też inne powody, m.in.: ukończenie kursu nie dawało żadnych konkretnych korzyści (kwalifikacji zawodowych itp.); prozaiczny brak odczuwania potrzeby udziału w kursie; negatywne opinie o jakości kursów (wielu nauczycieli nie posiadało kwalifikacji ani umiejętności pedagogicznych, częstokroć byli to ludzie bardzo młodzi i słabo wykształceni, a zarazem „obcy” tzn. spoza Śląska ${ }^{76}$.

\section{Podsumowanie}

Kursy repolonizacyjne $\mathrm{w}$ pierwotnym zamyśle nie miały na celu likwidacji, czy delegalizacji regionalnego języka Ślązaków. Przeciwnie, ze strony zarówno władz oświatowych, jak i nauczycielstwa padło wiele bardzo pozytywnych wypowiedzi na jej temat, jak o samych rodzimych mieszkańcach Opolszczyzny. Wskazywano na bogactwo mowy śląskiej w polskie archaizmy językowe, na jej staropolski rodowód, na konieczność jej chronienia i pielęgnacji, oraz konieczność podkreślania przy każdej sposobności jej silnego związku z polskim językiem literackim. Z naciskiem zwracano uwagę, że górnośląska mowa jest dowodem polskości tego regionu i jego mieszkańców. Kursy repolonizacyjne miały przede wszystkim cele praktyczne, wynikające z potrzeb wykreowanych przez ówczesne realia: nauczyć Ślązaków czytać, pisać i mówić po polsku, a to głównie celem ułatwienia im dalszego kształcenia się, jak również celem ogólnego ich odnalezienia się w no-

\footnotetext{
${ }^{74}$ Spraw. Urzędu Wojewódzkiego Śląskiego za III kwartał 1949 z 6 X 1949, APK, UWŚl., SP, t. 54/1.

75 P. Madajczyk, Przyłączenie..., s. 218; G. Strauchold, op. cit., s. 184.

76 Por. Z. Dulczewski, A. Kwilecki (oprac.), Pamiętniki osadników Ziem Odzyskanych, Poznań 1970, s. 388-395, 396-430; „Większość tępiła i ośmieszała gwarę śląską [...]", P. Madajczyk, Przyłączenie..., s. 197.
} 
wej rzeczywistości; cel polityczny - ukazać opinii międzynarodowej, że Ślązacy z własnej woli i chęci masowo garną się na kursy repolonizacyjne (a nie polonizacyjne), co miało być jednym z głównych argumentów za pozostawieniem w granicach Polski całego obszaru wraz z jego mieszkańcami (wykwalifikowanymi i doświadczonymi pracownikami przemysłu wydobywczo-hutniczego); cel ideologiczny - usunięcie ze śląskich umysłów „błędnych pojęć o Polsce i jej roli w Europie i świecie", tzn. pozyskać ich dla idei socjalizmu/komunizmu77. Zaś jedna z notatek, odnaleziona $\mathrm{w}$ archiwalnych dokumentach dotyczących kursów repolonizacyjnych na Opolszczyźnie wyjaśnia lapidarnie i dosadnie, iż „Celem kursów jest [...] związanie tej ludności z zagadnieniem socjalistycznego budownictwa Polski Ludowej i wykorzystania jej w produkcji"78. Kursy repolonizacyjne były bowiem jedynie jednym z narzędzi zapoczątkowanej w 1945 r. tzw. akcji repolonizacyjnej, zmierzającej do wykreowania wizerunku całego Górnego Śląska jako regionu polskiego w znaczeniu nie tylko historycz-

\footnotetext{
77 Spraw. wizytatora F. Błacha z podróży służbowej do Raciborza i powiatu raciborskiego odbytej w dniach 26-29 I 1948, APK, KOSŚl., t. 410; Referat Wiktora Wojciecha Jak uczyć języka polskiego na kursach repolonizacyjnych na Opolszczyźnie, wygłoszony w Większycach 18 XII 1946, ibidem, t. 450; Streszczenie referatu nauczyciela Pawła Wawrzycznego Jak uczę języka polskiego na kursach repolonizacyjnych, wygłoszonego 27 I 1948 w związku z lekcją pokazową przeprowadzoną w Uniwersytecie Ludowym w Brzeziu w czasie konferencji Związku Nauczycielstwa Polskiego powiatu raciborskiego poświęconej oświacie dorosłych, ibidem; Referat dr Zofii Tokarskiej Słownictwo na kursach języka polskiego, ibidem; Wytyczne programów kursów języka polskiego i kultury polskiej, ibidem; Materiały programowe do nauki na kursach repolonizacyjnych stopnia niższego i wyższego, ibidem; Rękopis: Praca na kursach repolonizacyjnych, jej znaczenie, cele, formy i metody, ibidem; Luźne pismo: Oświata Dorosłych, ibidem, t. 411; Program kursu przygotowawczego języka polskiego przy Państwowym Gimnazjum i Liceum dla Dorosłych w Opolu, ibidem; Protokół z posiedzenia WRN w Katowicach z 31 VII 1945, APK, WRN Kat., m-f 73370; Dokument: 0 pracy Zarządu Wojewódzkiego Towarzystwa Wiedzy Powszechnej w Katowicach [1957], APK, Komitet Wojewódzki Polskiej Zjednoczonej Partii Robotniczej w Katowicach, Wydział Propagandy, t. 125; Spraw. polustracyjne z 28 III 1952 przeprowadzone przez tow. Harasiemowicza Klemensa na okoliczność odbywającej się dyskusji nad II etapem Konstytucji na terenie Komitetu Powiatowego Lubliniec, ibidem, t. 10.

${ }^{78}$ Luźna notatka: Pomoc ludności rodzimej, APK, KOSŚl., t. 372. Wyróżnienie w cytacie - JP.
} 
Janusz Pfaff - Kursy repolonizacyjne na Śląsku Opolskim...

nym, ale także etniczno-kulturowym. Ślązacy posiadali wówczas także wielką wartość w znaczeniu gospodarczym jako zasoby ludzkie górnośląskiego przemysłu. Poprzez repolonizację starano się uchronić ich od masowego wysiedlenia, co na pozostałych terenach Ziem Odzyskanych było wówczas niemal normą ${ }^{79}$.

\section{Bibliografia (prace zwarte i artykuły):}

Boda-Krężel Z., Sprawa Volkslisty na Górnym Śląsku, Opole 1978.

Demkowski K., Pod znakiem rodła, [w:] K. Popiołek (red.), Wspomnienia nauczycieli śląskich, Katowice 1970.

Długoborski W., Pabisz J., Walka z uciskiem narodowym $i$ społecznym w latach 1922-1939, [w:] W. Długoborski (red.), Bytom. Zarys rozwoju miasta, Warszawa-Kraków 1979.

Dulczewski Z., Kwilecki A. (oprac.), Pamiętniki osadników Ziem Odzyskanych, Poznań 1970.

Dziurok A. (oprac.), Obóz pracy w Świętochłowicach w 1945 roku. Dokumenty, zeznania, relacje, listy, Warszawa 2002.

Dziurok A., Niedurny M. (red.), Deportacje Górnoślązaków do ZSRR w 1945 roku, Katowice 2004.

Dziurok A., Ślq̨skie rozrachunki. Władze komunistyczne a byli członkowie organizacji nazistowskich na Górnym Śląsku w latach 1945-1956, Warszawa 2000.

Filipkowski T., Repolonizacja ludności rodzimej Warmii i Mazur w latach 19451950, [w:] R. Rauziński, S. Senft (red.), Polska ludność rodzima na Ziemiach Zachodnich i Północnych po II wojnie światowej. Materiały z sympozjum naukowego w Instytucie Śląskim w Opolu w dniu 25 listopada 1988 r., Opole 1989.

Gacki W. (red.), Podręczny poradnik dla kierowników i nauczycieli szkół powszechnych, Łódź 1932.

Gąszczyński M., Oświata dla dorosłych, [w:] T. Musioł (red.), Oświata na Opolszczyźnie w latach 1945-1959, Katowice 1961.

${ }^{79}$ Zagadnienie to wykracza poza ramy niniejszego artykułu. Dlatego ograniczę się tu jedynie do odesłania czytelnika do opublikowanych źródeł, zawierających obszerne wypowiedzi na ten temat ówczesnych polityków, zarówno polskich jak i zagranicznych: W. Wrzesiński (red.), W stronę Odry i Bałtyku. Wybór źródeł (1795 - 1950), t. IV: Od Poczdamu do Zgorzelca (1945 - 1950), Wrocław-Warszawa 1991; W. Mensz (red.), Teheran-Jałta-Poczdam. Dokumenty konferencji szefów rządów trzech wielkich mocarstw, Warszawa 1972; G. Rysiak (oprac.), Zachodnia granica Polski na konferencji poczdamskiej. Zbiór dokumentów, Opole 1970. 
Glimos-Nadgórska A., Polskie szkolnictwo powszechne województwa ślq̨skiego (1922-1939), Katowice 2000.

Grajpel A., Kartki z pamiętnika ślq̨skiego nauczyciela, [w:] K. Popiołek (red.), Wspomnienia nauczycieli..., op. cit..

Gruschka G., Zgoda - miejsce grozy. Obóz koncentracyjny w Świętochłowicach, Gliwice 1998.

Hasiński M., Praca kulturalno-oświatowa na Opolszczyźnie, „Zaranie Śląskie” 1947, z. 1-2.

Kantyka J., Zieliński W. (red.), Śląski Słownik Biograficzny, t. 2, Katowice 1979.

Kosiński Z., Przeobrażenia demograficzne na Ziemiach Zachodnich, [w:] W. Markiewicz, P. Rybicki (red.), Przemiany społeczne na Ziemiach Zachodnich, Poznań 1967.

Kotula O., Szkolnictwo w województwie śląsko-dąbrowskim w latach 1945-1946, „Zaranie Śląskie” 1947, z. 1-2.

Kowalski Z., Powrót Śląska Opolskiego do Polski. Organizacja władzy ludowej i regulacja problemów narodowościowych w latach 1945-1948, Opole 1983.

Linek B., Polityka antyniemiecka na Górnym Śląsku w latach 1945-1950, Opole 2000.

Łempiński Z., Przesiedlenie ludności niemieckiej z województwa śląsko-dąbrowskiego w latach 1945-1950, Katowice 1979.

Madajczyk P., Obozy pracy na ziemiach zachodnich i północnych przed i po 1948 roku, [w:] C. Osękowski (red.), Ziemie Zachodnie i Północne Polski w okresie stalinowskim, Zielona Góra 1999.

Madajczyk P., Przyłq̨czenie Ślq̨ska Opolskiego do Polski 1945-1948, Warszawa 1996.

Mensz W. (red.), Teheran-Jałta-Poczdam. Dokumenty konferencji szefów rzq̨dów trzech wielkich mocarstw, Warszawa 1972.

Misztal J., Weryfikacja narodowościowa na Ślasku Opolskim 1945-1950, Opole 1984.

Nowakowski S., Adaptacja ludności na Ślq̨sku Opolskim, Poznań 1957.

Olejnik L., Ziemie Odzyskane $w$ polityce narodowościowej państwa polskiego w latach 1945-1949, „Przegląd Zachodni” 1999, nr 3.

Osękowski C., Społeczeństwo Polski Zachodniej i Północnej w latach 1945-1956. Procesy integracji i dezintegracji, Zielona Góra 1994.

Półturzycki J., Rozwój i problemy szkolnictwa dla dorosłych w Polsce Ludowej, Wrocław-Warszawa-Kraków-Gdańsk 1972.

Rauziński R., Przeobrażenia społeczno-demograficzne ludności na Ziemiach Zachodnich w latach 1945-1985, [w:] R. Rauziński, S. Senft (red.), Polska ludność..., op. cit. 
Janusz Pfaff - Kursy repolonizacyjne na Śląsku Opolskim...

Rysiak G. (oprac.), Zachodnia granica Polski na konferencji poczdamskiej. Zbiór dokumentów, Opole 1970.

Sakson A., Miejsce i rola ludności rodzimej w społecznościach lokalnych na przykładzie Warmii i Mazur w latach 1945-1956, [w:] R. Rauziński, S. Senft (red.), Polska ludność..., op. cit.

Senft S., Sytuacja polskiej ludności rodzimej na Ziemiach Zachodnich i Północnych w latach 1945-1956 (na przykładzie Śląska Opolskiego), [w:] R. Rauziński, S. Senft (red.), Polska ludność..., op. cit.

Serafin F., Ruch Ludowy w województwie ślqqsko-dq̨browskim w latach 1945-1949, Katowice 1970.

Siemieński M., Zagadnienia szkolnictwa dla dorosłych. Organizacja - nauczanie, Kraków 1951.

Sławiński F., Pierwsze kroki na odzyskanej ziemi, [w:] Z. J. Bolek (wybór), Wróciła Polska. Pamiętniki z pierwszych lat powojennych na Ziemiach Odzyskanych, Warszawa 1974.

Strauchold G., Autochtoni polscy, niemieccy, czy... Od nacjonalizmu do komunizmu (1945-1949), Toruń 2001.

Śleziona J., Pamiętnik polskiego rechtora, [w:] R. Hajduk (red.), Pamiętniki Opolan, Kraków 1954.

Topol A. (red.), Obozy pracy przymusowej na Górnym Śląsku, Katowice 1994.

Walczak J., Jerzy Ziętek. Biografia Ślq̨zaka (1901-1985), Katowice 2002.

Wrzesiński W. (red.), W stronę Odry i Bałtyku. Wybór źródeł (1795 - 1950), t. IV: Od Poczdamu do Zgorzelca (1945 - 1950), Wrocław-Warszawa 1991.

Wrzesiński W., Postawy i nastroje Polaków na Górnym Ślq̨sku w latach II wojny światowej, [w:] W. Wrzesiński (red.), Górny Śląsk i Górnoślązacy w II wojnie światowej, Bytom 1997.

Zawadzki A., Notatki, przemówienia 1945-1948 na Śląsku i w Zagłębiu Dąbrowskim, tekst autoryzowany, wybór W. Janiurek, W. Szewczyk, Katowice 1964. 